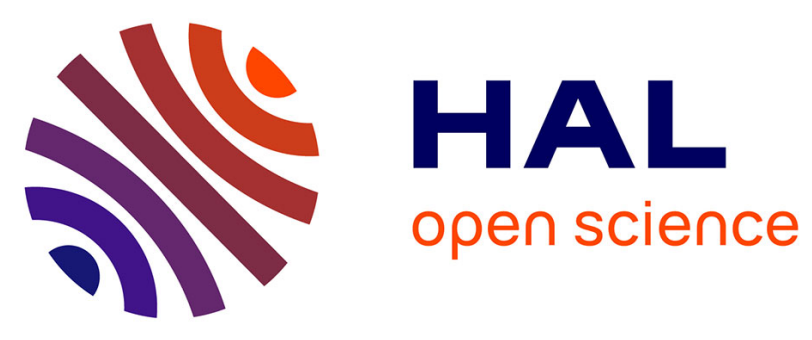

\title{
Global and local forcing of Early Toarcian seawater chemistry: A comparative study of different paleoceanographic settings (Paris and Lusitanian basins)
}

Michaël Hermoso, Fabrice Minoletti, Laurence Le Callonnec, Hugh C. Jenkyns, Stephen P. Hesselbo, Rosalind E.M. Rickaby, Maurice Renard, Marc de Rafélis, Laurent Emmanuel

\section{To cite this version:}

Michaël Hermoso, Fabrice Minoletti, Laurence Le Callonnec, Hugh C. Jenkyns, Stephen P. Hesselbo, et al.. Global and local forcing of Early Toarcian seawater chemistry: A comparative study of different paleoceanographic settings (Paris and Lusitanian basins). Paleoceanography, 2009, 24 (PA4208), pp.115. 10.1029/2009PA001764 . hal-00694401

\section{HAL Id: hal-00694401 https://hal.science/hal-00694401}

Submitted on 12 Jan 2022

HAL is a multi-disciplinary open access archive for the deposit and dissemination of scientific research documents, whether they are published or not. The documents may come from teaching and research institutions in France or abroad, or from public or private research centers.
L'archive ouverte pluridisciplinaire HAL, est destinée au dépôt et à la diffusion de documents scientifiques de niveau recherche, publiés ou non, émanant des établissements d'enseignement et de recherche français ou étrangers, des laboratoires publics ou privés.

$$
\text { Copyright }
$$




\title{
Global and local forcing of Early Toarcian seawater chemistry: A comparative study of different paleoceanographic settings (Paris and Lusitanian basins)
}

\author{
Michaël Hermoso, ${ }^{1,2}$ Fabrice Minoletti, ${ }^{2}$ Laurence Le Callonnec, ${ }^{2}$ Hugh C. Jenkyns, ${ }^{1}$ \\ Stephen P. Hesselbo, ${ }^{1}$ Rosalind E. M. Rickaby, ${ }^{1}$ Maurice Renard, ${ }^{2}$ Marc de Rafélis, ${ }^{2}$ \\ and Laurent Emmanuel ${ }^{2}$
}

Received 12 March 2009; revised 2 July 2009; accepted 13 August 2009; published 6 November 2009.

[1] The Early Toarcian was characterized by two large perturbations to the carbon cycle: a positive trend associated with increased organic matter burial and ocean anoxia, and a pronounced negative carbon isotope excursion (CIE). We contrast the geochemical evolution in the carbonate phases of two successions: one from the Paris Basin (Sancerre core, comprising black shales), the other from the Lusitanian Basin (Peniche section with very minor lithological expression of bottom water anoxia). Our aim was to identify whether these carbon cycle perturbations were related, and differentiate between the common (global) versus regional expressions of the biogeochemical response and ocean chemistry. Our results highlight contrasts in timing of different phases of anoxia in both locations through the widely documented negative CIE. Widespread anoxic conditions were not a necessary prerequisite for generating a pronounced CIE, as required by the recycling (so-called "Küspert") model. The production of carbonate simultaneously dropped during the $\delta^{13} \mathrm{C}$ negative shift in both locations, likely in response to lowered seawater saturation rate induced by substantial absorption of $\mathrm{CO}_{2}$ from the atmosphere. The recovery interval was accompanied by a rapid reestablishment of seawater alkalinity, and primary and carbonate productivity in epicontinental seas, as evidenced by high $\delta^{13} \mathrm{C}$ and $\mathrm{Sr} / \mathrm{Ca}$, in contrast with the more open ocean regime in the Lusitanian Basin. Our results confirm that parallels can be draw between the ocean productivity response and feedback during the Toarcian CIE and the PETM. Both events are characterized by ocean acidification and reduced pelagic calcification followed by a peak in nearshore coccolith productivity, which could have helped the recovery from the perturbation.

Citation: Hermoso, M., F. Minoletti, L. Le Callonnec, H. C. Jenkyns, S. P. Hesselbo, R. E. M. Rickaby, M. Renard, M. de Rafélis, and L. Emmanuel (2009), Global and local forcing of Early Toarcian seawater chemistry: A comparative study of different paleoceanographic settings (Paris and Lusitanian basins), Paleoceanography, 24, PA4208, doi:10.1029/2009PA001764.

\section{Introduction}

[2] The Early Toarcian (Early Jurassic; $~ 183$ Ma ago) has attracted considerable attention over the last four decades because of the major disturbance in the global carbon cycle, categorized as an Oceanic Anoxic Event (OAE hereafter) [Jenkyns, 1985, 1988]. Although such a globally significant organic carbon burial event apparently resulted in an overall positive excursion of the carbon isotope ratio in seawater, the T-OAE is also punctuated by one of the largest negative CIE of Mesozoic times, which occurred over a short period, 200-1000 ka [Kemp et al., 2005; Suan et al., 2008a]. Compelling evidence for a perturbation of the whole ocean-atmosphere system has led to the interpretation of this CIE in terms of massive release of isotopically light $\mathrm{CH}_{4} / \mathrm{CO}_{2}$ (Hesselbo et al. [2000], Kemp et al. [2005], and Hesselbo et al. [2007] among others). However, the causes

\footnotetext{
${ }^{1}$ Department of Earth Sciences, University of Oxford, Oxford, UK

${ }^{2}$ Laboratoire Biominéralisations et Environnements Sédimentaires, ISTeP, UMR 7193, UPMC Université Paris 6, Paris, France.

Copyright 2009 by the American Geophysical Union. 0883-8305/09/2009PA001764
}

of the carbon isotope perturbation, and the synchroneity of its record, remain controversial [van de Schootbrugge et al., 2005; Wignall et al., 2006; McArthur, 2007; McArthur et al., 2008a, 2008b] with the suggestion that local (i.e., environmentally driven) processes, as originally postulated by Küspert [1982], could best explain the negative CIE at times of basinal restriction.

[3] The near synchroneity between the T-OAE and the negative $\mathrm{C}$ isotope perturbation has led to potentially misleading interpretations of a common origin for these two paleoceanographic phenomena. Organic enrichment in the sedimentary record and carbon isotope perturbation, albeit linked through involvement of the short-term global carbon cycle, need to be examined separately because their stratigraphic extent is not necessarily the same [Hesselbo et al., 2000; McArthur et al., 2008a; Pearce et al., 2008; Hermoso et al., 2009]. Here, we examine the stratigraphical distribution of the redox-sensitive elements $\mathrm{Fe}$ and $\mathrm{Mn}$, and the paleoproductivity marker $\mathrm{Sr}$ and $\mathrm{Mg}$ in the context of calcite/dolomite content through the interval characterized by the negative carbon isotope excursion as recorded in two distinct environments, represented by epicontinental organicrich black shales (Sancerre core, Paris Basin, France), and 


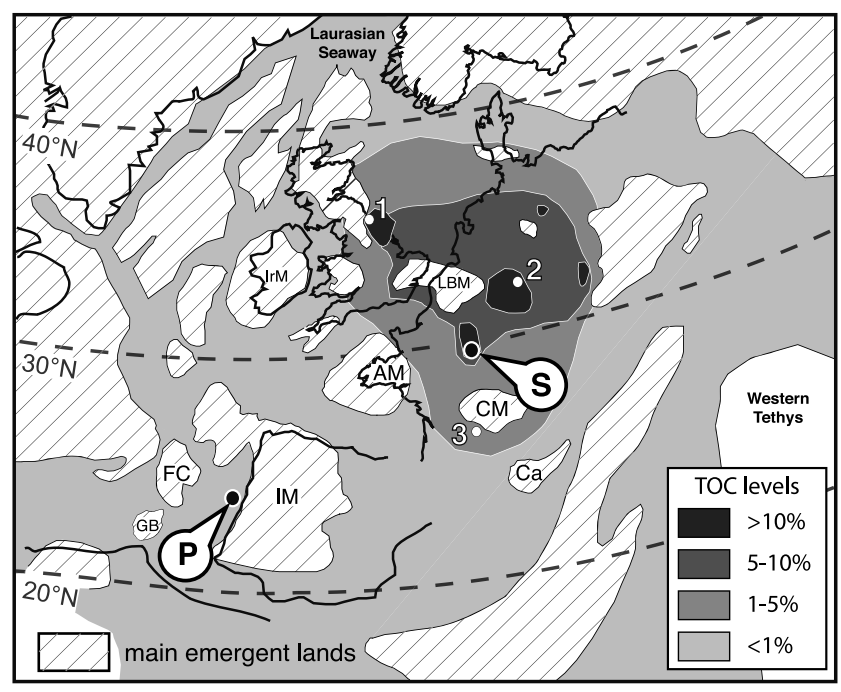

Figure 1. Paleogeographic map of the Early Jurassic archipelago (redrawn after van de Schootbrugge et al. [2005]) and the geographic distribution of organic-rich rocks [after Baudin et al., 1990] (AAPGC) 1990 reprinted by permission of the AAPG whose permission is required for further use). Gray scale shades indicate the content range of Total Organic Carbon (TOC); key is embedded in the bottom right corner. Emergent land delineating the basins is hatched: IrM for Irish Massive, LBM for London-Brabant Massif, AM for Armorican Massif, CM for Central Massif, $\mathrm{Ca}$ for Calabria, IM for Iberian Meseta, FC for Flemish Cap, and GB for Galicia Bank. Letters are for the studied locations: " $\mathrm{S}$ " is for Sancerre-Couy core site, and " $\mathrm{P}$ " is for Peniche section. Numbers locate other Early Toarcian sections referred to in this work: 1, Yorkshire coast [Hesselbo et al., 2000; Cohen et al., 2004; Kemp et al., 2005]; 2, Dotternhausen in Germany [Röhl et al., 2001]; and 3, Penne section in Quercy Basin [Emmanuel et al., 2006].

organic-poor hemipelagic carbonates (Peniche, Lusitanian Basin, Portugal).

\section{Geological Setting in the Paris and Lusitanian Basins During the Early Toarcian}

\subsection{Paleogeography and Paleoclimatic Patterns}

[4] During the Early to Middle Jurassic, the breakup of Pangaea took place, with the opening of the Central Atlantic and Tethys Ocean, accompanied by widespread tectonic extension in what is now the Alpine-Mediterranean region, as well as in northern Europe [Bernoulli and Jenkyns, 2009]. In the Tethyan region, the widespread drowning of carbonate platforms led to progressive invasion of pelagic conditions, typified by the development of deep-water carbonates on subsided continental margins. On the European shelf, silts, sands, clays and shallow water limestones were deposited. The presence of numerous emerged landmasses in NW Europe favored high detrital mineral supply into adjacent marine areas. The paleolatitude during this interval (Figure 1) was about $30^{\circ} \mathrm{N}$ for the Paris Basin and about $25^{\circ} \mathrm{N}$ for the Lusitanian Basin [Bassoullet et al., 1993]. The Early Jurassic is thought to have been predominantly a greenhouse period, whose $\mathrm{CO}_{2}$-rich atmosphere, particularly in the Toarcian, was charged by intense magmatic activity in the Karoo-Ferrar Province [Duncan et al., 1997; Pálfy et al., 1997; Wignall, 2001; Svensen et al., 2007; Moulin et al., 2008; Jourdan et al., 2008]. In this context, the earliest Toarcian biosphere underwent significant turnover with extinctions affecting both marine and continental faunas [Hallam, 1983, 1996; Bassoullet and Baudin, 1994; Little and Benton, 1995; Harries and Little, 1999; Pálfy and Smith, 2000; Bailey et al., 2003]. Among the discrete black shale intervals encountered through the whole Early Jurassic succession in Europe, the sediments that formed during the T-OAE were associated with the strongest anoxic/euxinic conditions [Jenkyns, 1988; Baudin et al., 1990; Jenkyns et al., 2002; Pancost et al., 2004; Schwark and Frimmel, 2004; Pearce et al., 2008]. For the OAE, accelerated flux of nutrients to the ocean, accompanied by sea level rise [Hallam, 1997] is thought to have led to an increase in organic productivity, carbon flux to the seafloor, carbon burial, and spread of anoxic and euxinic waters, combining to explain the long term increase in $\delta^{13} \mathrm{C}$ seawater ratios and the destruction of habitats for marine life [Jenkyns, 2003]. We have selected two sites of contrasting proximal and more open marine settings to investigate the differential sedimentary characteristics and highlight the global versus regional signatures of the T-OAE and CIE.

\subsection{Sancerre Core and the Southernmost Paris Basin}

[5] The Sancerre-Couy borehole was drilled in 19861987 near Bourges city (central France) by the French Bureau des Recherches Géologiques et Minières (program GPF "Géologie Profonde de la France"). This region was located in the southernmost Paris Basin during the Jurassic (Figure 1). The borehole has provided continuous recovery from Carboniferous up to the Middle Jurassic strata. The Toarcian sediments occur between 355.50 and $198.30 \mathrm{~m}$ depth and were fully recovered (albeit with localized drilling disturbances). The lithology (Figure 2a) of the Late Pliensbachian spinatum Zone is represented by marine calcareous sandstones with a high contribution of detrital quartz (Grès médioliasiques Fm), succeeded by coccolithbearing calcareous marls with several organic-rich and laminated intervals (Schistes Carton Fm, up to 10\% total organic carbon) assigned to the tenuicostatum and serpentinum Zones (33m thick in Sancerre). Within the Schistes Carton and the laterally equivalent lithostratigraphic units in NW Europe, evidence to support marine anoxia is represented by millimeter-scale sedimentary lamination and the absence of bottom-dwelling fauna. Evidence for a sulfidic (euxinic) water column extending into the photic zone is provided by biomarkers of green sulfur bacteria [Pancost et al., 2004; Schwark and Frimmel, 2004; van Breugel et al., 2006], and $\sim 5 \mu \mathrm{m}$ sized framboidal pyrite precipitated from seawater [Raiswell and Berner, 1985; Wilkin et al., 1996; Wilkin and Barnes, 1997; Bellanca et al., 1999; Wignall et al., 2005]. The paleodepth of the Paris Basin (Figure 1), which represents a subbasin of the north European epicontinental 
(a) SANCERRE

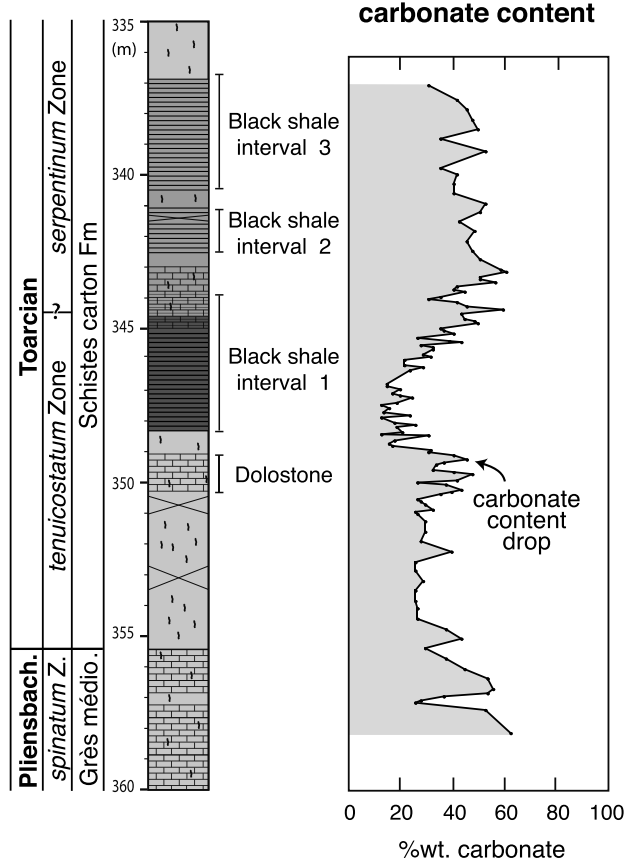

C-isotope profile
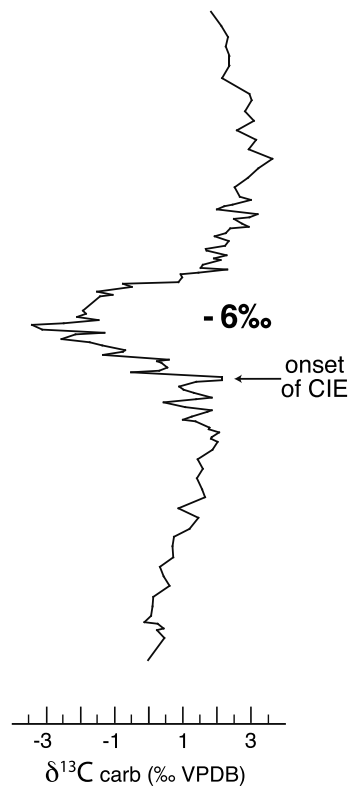

C-isotope profile

carbonate content

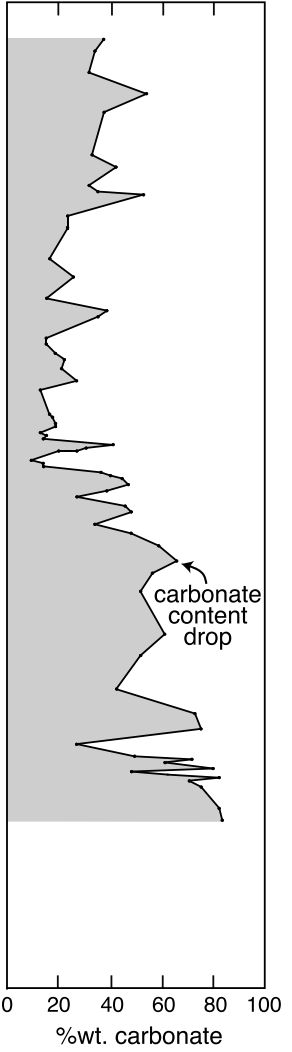

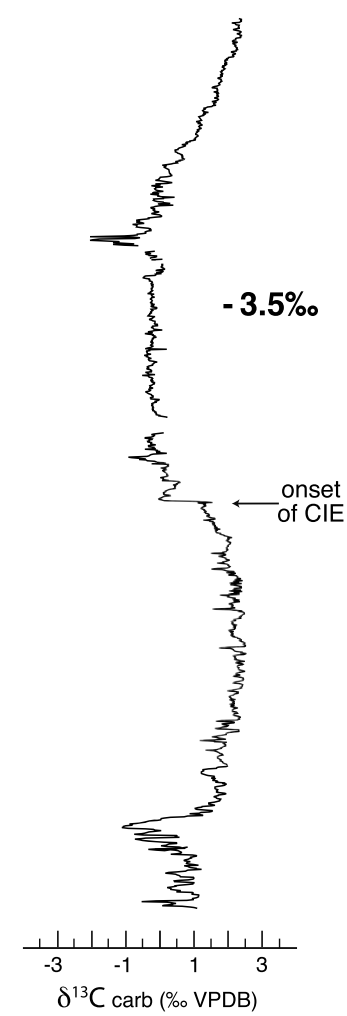

O-isotope profile

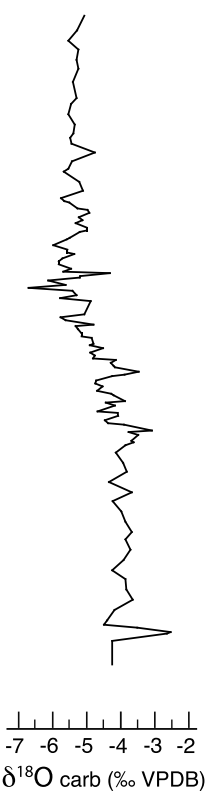

O-isotope profile

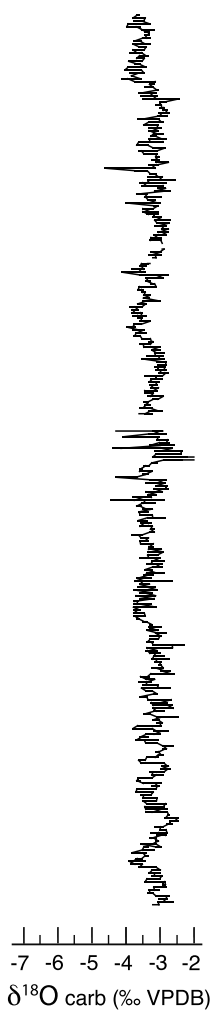

Lithology

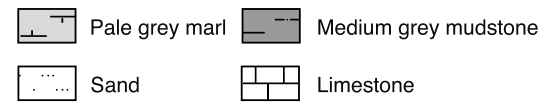

Laminated mudstone $\because \therefore 0^{\circ}$ Conglomerate

Figure 2 
seaway, is estimated as $100-200 \mathrm{~m}$ during the Early Toarcian interval [Röhl et al., 2001].

\subsection{Peniche Section and the Lusitanian Basin}

[6] This section crops out along the Peniche beach, about $80 \mathrm{~km}$ north of Lisbon (Figure 1). The outcrop is considered as the most appropriate candidate for the stratotype of the Pliensbachian/Toarcian boundary GSSP [Elmi, 2006]. The Latest Pliensbachian (spinatum Zone) and very earliest Toarcian (polymorphum Zone $\approx$ tenuicostatum in the Boreal realm) correspond to the Lemede Fm (Figure 2b), deposited on a monoclinal carbonate ramp formed in response to regional extensional tectonic control [Duarte, 1997]. The facies comprise alternations of hemipelagic limestones and marls. The top of the polymorphum and the whole of the levisoni ( $\approx$ serpentinum in the Boreal realm) Zones are represented by the Cabo Carvoeiro Fm, a more argillaceous succession containing some intercalations of carbonate nodules at its base and quartzose turbidites at its top.

[7] In contrast to the more Boreal NW European realm, the marine organic carbon content in Peniche is relatively low $(<1 \%)$ compared with coeval sediments deposited in Northern Europe. Furthermore, in Peniche the organic matter mostly consists of terrestrial components, although a more organic-rich interval $(2.6 \%$ TOC) is present as an $8 \mathrm{~cm}$ thick bed in the levisoni Zone [Hesselbo et al., 2007]. Whether truly anoxic conditions occurred in Peniche is difficult to assess because sedimentary evidence such as well-defined lamination or high phytoplanktonic organic content are lacking, as observed in the Schistes carton Fm of the Paris Basin. The apparently more oxic nature of this environment, as illustrated by the existence of benthic organisms [Suan et al., 2008b], motivated our choice to investigate its evolving seawater geochemistry.

\section{Analytical Methods}

\subsection{Mineralogical Data}

\subsubsection{Total Carbonate Content}

[8] The total carbonate content was determined by weighing the insoluble fraction of the sediment after acid digestion. The carbonate of one gram of crushed sample was digested in dilute acetic acid $\mathrm{CH}_{3} \mathrm{COOH}(1 \mathrm{~mol} / \mathrm{l})$ for $1 \mathrm{~h}$ at room temperature, with continuous stirring. The residue was gathered on a cellulose acetate filter, which was dried and weighed. The percentage of total carbonate content is expressed as "wt \% carbonate" with a precision generally greater than $99 \%$. Replicates of low-carbonate samples have indicated larger errors, but less than 5\%. Finally, XRD analyses (see below) were performed on preparations from residues to ensure the complete digestion of all carbonate phases, especially dolomite.

\subsubsection{Calcite/Dolomite Ratio}

[9] The carbonate mineral species of the sediment were identified by X-ray diffraction using a Brucker D-501 X-ray diffractometer (radiation $\mathrm{Cu} \alpha 1$ - Ni filtered radiation, $\lambda=$ $1.54060 \AA$ ) coupled with an automated DACO-MP system at UPMC Paris. Scans were performed from $3^{\circ}$ to $75^{\circ} 2 \Theta$ at a scanning speed of $0.05^{\circ} 2 \Theta / \mathrm{sec}$. Semiquantitative measurements of carbonate mineral abundances (calcite versus dolomite ratio) were obtained from nonoriented powdered samples. The intensities of the main diffracting peaks (104) of the calcareous phases were corrected according to their respective "I/Icorr" factors, as given by the International Centre for Diffraction Data (ICDD) in the Powder Diffraction File (PDF) database. Corrections applied were 2.00 for the calcite with $d_{104}$ between 3.035 to $3.025 \AA$, and 2.35 for the dolomite with $d_{104}$ measured at $\sim 2.91 \AA$, corresponding to a dolomite with a low crystallinity index [Hermoso et al., 2009]. Such a dolomite phase diffracting at $2.91 \AA$ rather than $2.88 \AA$ has been found in other black shale localities in Italy [Bellanca et al., 1999], and this offset toward lower diffracting angles has been explained by these authors by substantial manganese coprecipitation into the dolomite lattice.

\subsection{Elemental Content}

\subsubsection{Carbonate Digestion}

[10] The carbonate phase was digested according to the procedure described above. A number of experimental tests [Renard and Blanc, 1972] have shown that the solubilized ions from this weak acid leach mostly come from the carbonate lattice, as indicated by a good correlation between $\mathrm{Mg}$ - and Fe-rich carbonate quantified by the XRD method, and the magnesium and iron from chemical measurement. The presence of oxyhydroxides is not likely in such dysoxic and anoxic sediments. Indeed, framboidal pyrite observed from the residues is always well preserved, and never exhibits evidence of oxidation such as superficial reddish rings. The iron content of the black shale associated with maximum sulfide content is relatively low when compared with associated clay-rich limestone. This observation rules out a significant contribution of the interfoliar cations from clays to the elemental measurements.

[11] The filtrate solution comprises all the dissolved ions originally contained in the carbonate lattice. Because acetate ions are prone to interfere with spectrometric measurement, the filtrates were evaporated and placed in a hydrochloric solution by adding $20 \mathrm{ml} 30 \% \mathrm{HCl}$. This process was repeated twice. Homogenization of the calcium content of

Figure 2. Carbonate content and carbon and oxygen isotope profiles measured in Upper Pliensbachian/Lower Toarcian marine carbonates. (a) The Sancerre-Couy core [Hermoso et al., 2009]. The $\delta^{13} \mathrm{C}$ negative shift is recorded in four consecutive steps. The amplitude of the CIE is $\sim-6 \%$ leading to $\delta^{13} \mathrm{C}$ around $-4.5 \%$ after which a notable positive trend is observed. A decrease in the carbonate content and a $-1.5 \%$ negative shift in oxygen isotopes are recorded through the negative CIE. (b) The Peniche section (isotopic data and log from Hesselbo et al. [2007]). The isotopic curve presented here does not include the turbidite levels. The amplitude of the CIE is $\sim-3.5 \%$ associated with a $\delta^{13} \mathrm{C}$ low-value plateau around $-0.5 \%$. A drop in the carbonate content is observed slightly before the negative CIE, but the oxygen isotope profile is relatively constant through the $\delta^{13} \mathrm{C}$ negative shift, around $-3 \%$. 
the solutions and standards was achieved by differing dilution of the solution for each considered element.

\subsubsection{Spectrometric Analyses}

[12] The solutions were measured by flame atomic absorption (ICP-GAAS) using a Hitachi Z8100 spectrometer at UPMC Paris. The internal standards were measured along with the sample solutions and blanks. The elemental contents are expressed in ppm after normalization against the carbonate fraction of the sediment. The precision of measurements is usually better than $95 \%$, based on the reproducibility of the standard and sample replicates. See auxiliary material for further information. ${ }^{1}$

\section{Results}

\subsection{Carbonate Content and Mineralogy}

\subsubsection{Sancerre Core}

[13] Fluctuations of the total carbonate content (Figure 2a) range from $15 \%$ to $60 \%$. In the Lower Toarcian section, the carbonate contents are approximately constant, about 25 $30 \%$ with a low contribution from dolomite (less than $20 \%$ with respect to the whole carbonate; Figure $3 a$ ). Between $350.35 \mathrm{~m}$ to $349.22 \mathrm{~m}$, a gray and more indurated bed is observed that is mainly composed of dolomite $(80 \%$ of the carbonate).

[14] At the top of this dolostone, a significant decrease in the carbonate content is observed, which can be explained as the return to background dolomite abundance. This decrease is associated with the first step of the negative CIE [Hermoso et al., 2009]. However, there is a drop in calcite content between this level, in which the $\mathrm{wt} \% \mathrm{CaCO}_{3}$ is $\sim 15-20 \%$, and the sediment underneath the dolostone, which is $\sim 40 \%$ calcium carbonate. At $348.50 \mathrm{~m}$, the sediment becomes laminated and dark; its carbonate content is $\sim 15 \%$. At this level, the second step in the $\delta^{13} \mathrm{C}$ decrease is recorded. This low-carbonate interval persists up to about $347 \mathrm{~m}$, where the preservation of calcareous nannofossils significantly decreases [Hermoso et al., 2009]. The dolomite content is particularly low in this black shale interval.

[15] The $\delta^{13} \mathrm{C}$ rise coincides with an increase in carbonate content up to the $344 \mathrm{~m}$ level, where the carbonate content reaches about $60 \%$. Above this, a progressive decrease in carbonate (from 60 to $30 \%$ ) is observed up to the top of the studied interval. Other laminated and organic-rich intervals are, however, not associated with decreases in carbonate content. Local occurrences of high dolomite content (10$20 \%$ ) are observed, as at the $344 \mathrm{~m}, 341.5 \mathrm{~m}$, and $337 \mathrm{~m}$ levels.

\subsubsection{Peniche Section}

[16] The carbonate content in Peniche (Figure 2b) is significantly different in the Upper Pliensbachian interval ( $\sim 80 \%$ carbonate) compared to the Lower Toarcian Cabo Carvoeiro marls (decreasing from $75 \%$ to $40 \%$ in the polymorphum Zone and $\sim 20-30 \%$ in the levisoni Zone). In the polymorphum Zone, a progressive decrease in carbonate content is observed, with only minor dolomite present (Figure 3b).

\footnotetext{
${ }^{1}$ Auxiliary materials are available at ftp://ftp.agu.org/apend/pa/ $2009 \mathrm{pa} 001764$.
}

[17] From $6.5 \mathrm{~m}$, the decrease becomes more pronounced and, at about $11 \mathrm{~m}$, a sharp drop in calcite abundance is observed, leading to carbonate contents of $\sim 10 \%$. This level corresponds to the onset of the $\delta^{13} \mathrm{C}$ negative excursion illustrated in the work of Hesselbo et al. [2007]. Through the plateau characterized by the lowest $(\sim-0.5 \%)$ carbon isotope values $(11 \mathrm{~m}-19.5 \mathrm{~m})$, the carbonate content is steady and comprises between 10 and $40 \%$ of the sediment. The dolomite is, however, highly variable in abundance: it can be particularly high (reaching $40 \%$ at $13 \mathrm{~m} ; 20 \%$ at $14 \mathrm{~m}$ and $15 \%$ at $16 \mathrm{~m}$ ) with respect to the overall background contents $(<5 \%$ of carbonate).

[18] Above $19.5 \mathrm{~m}$, the carbonate content displays a progressive increase, which follows the resumed positive $\delta^{13} \mathrm{C}$ trend, as also seen in Sancerre.

\subsection{Magnesium and Iron and $\mathrm{Mg} / \mathrm{Fe}$ Ratio in Dolomite}

\subsubsection{Sancerre Core}

[19] The evolution of both magnesium and iron contained in the carbonate of the Sancerre core follows the same trend (Figure 3a). There is a strong correlation factor $(r=0.86)$ that links these two elements in the carbonate throughout the studied interval (Figure 4a). The high concentrations ( $\sim 20,000 \mathrm{ppm}$ and $\sim 10,500 \mathrm{ppm}$, respectively) are explained by the presence of ferroan protodolomite, as indicated by the positive correlation of these two elements with the dolomite proportion of the whole carbonate phase $(\mathrm{r}=0.90)$. A positive trend is observed through the Upper Pliensbachian interval with relatively high contents around the stage boundary with the Toarcian (355.50 m; $\mathrm{Mg} \sim 26,000 \mathrm{ppm}, \mathrm{Fe} \sim 20,000 \mathrm{ppm}$ ). In the lowermost Toarcian sediments, the contents are lower and steady up to where the dolostone is developed above the $350 \mathrm{~m}$ level. In this bed, the $\mathrm{Mg}$ and $\mathrm{Fe}$ contents are at a maximum and reach $\sim 60,000 \mathrm{ppm}$ and $\sim 40,000 \mathrm{ppm}$, respectively.

[20] The bioturbated marls that cap the dolostone and record the first step of the negative CIE record a significant decrease in the $\mathrm{Mg} / \mathrm{Fe}$ contents toward values lower than those measured underneath the dolostone. Higher in the section, a stratigraphically limited increase is noted between $348.80 \mathrm{~m}$ and $348.40 \mathrm{~m}$. At the first occurrence of black shale facies $(348.30 \mathrm{~m})$, both $\mathrm{Mg}$ and Fe display a parallel decrease. During the interval characterized by the lowest $\delta^{13} \mathrm{C}$ value, magnesium and iron contents are relatively low $(15,000 \mathrm{ppm}$ for $\mathrm{Mg}$ with a progressive drop throughout the CIE, and $5000 \mathrm{ppm}$ for iron), in accordance with a low dolomite contribution.

[21] Above $345 \mathrm{~m}$, the contents of $\mathrm{Mg}$ and $\mathrm{Fe}$ are relatively low and stable up to the top of the investigated interval, but they increase together with the higher dolomitic contents at levels of $344.00 \mathrm{~m}, 341.50 \mathrm{~m}$ and $337.00 \mathrm{~m}$.

\subsubsection{Peniche Section}

[22] A strong $\mathrm{Mg} / \mathrm{Fe}$ correlation $(\mathrm{r}=0.93)$ is also observed in Peniche (Figure 4a); values are also closely linked to the amount of dolomite in the carbonate. The dolomite is expressed as the same mineralogical phase, crystal shape and size as in Sancerre (as $\sim 5$ to $10 \mu \mathrm{m}$ subeuhedral crystals). The Pliensbachian/Toarcian boundary does not record any significant changes in the $\mathrm{Mg}$ and $\mathrm{Fe}$ 
(a) SANCERRE
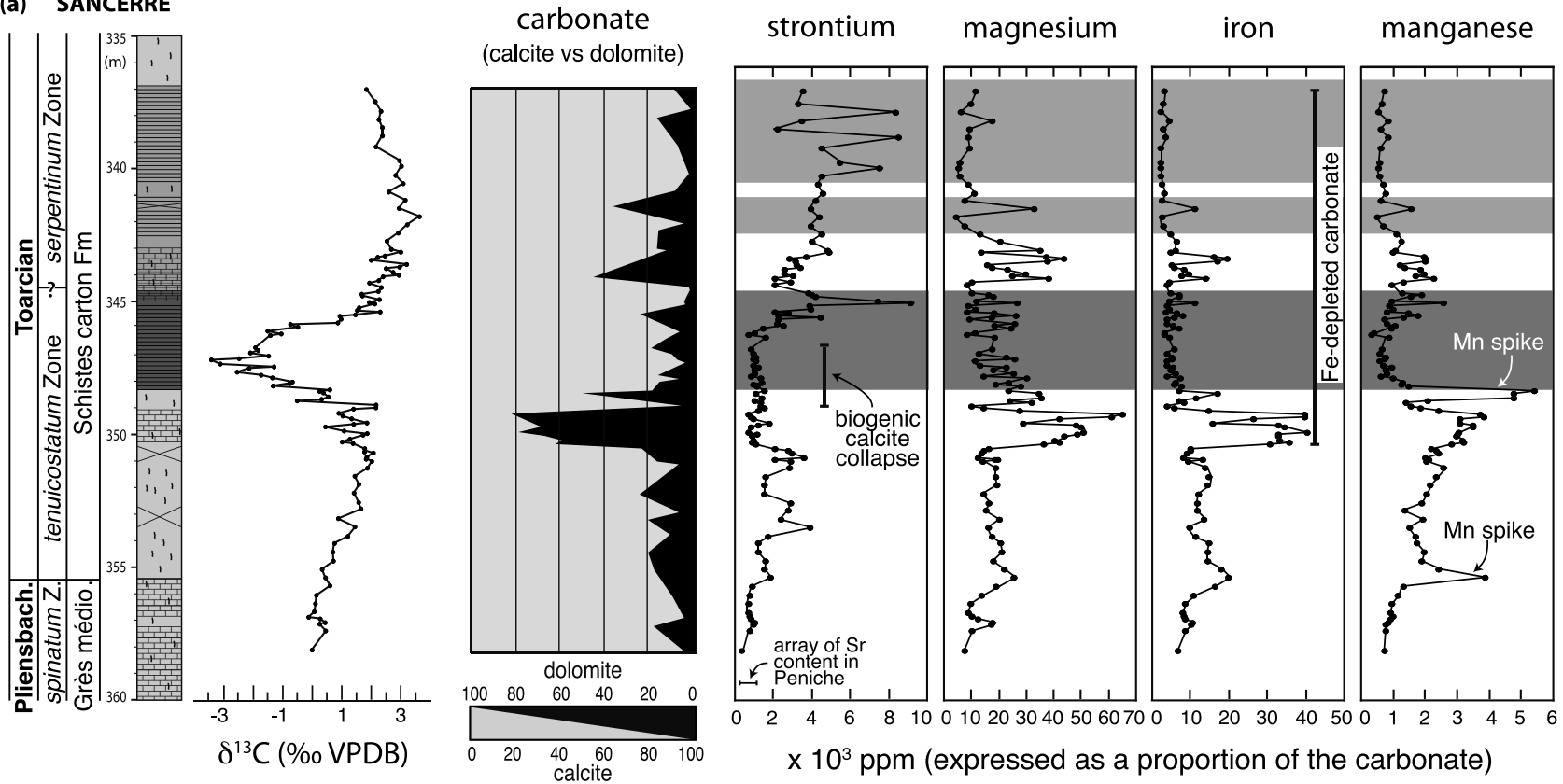

(b) PENICHE
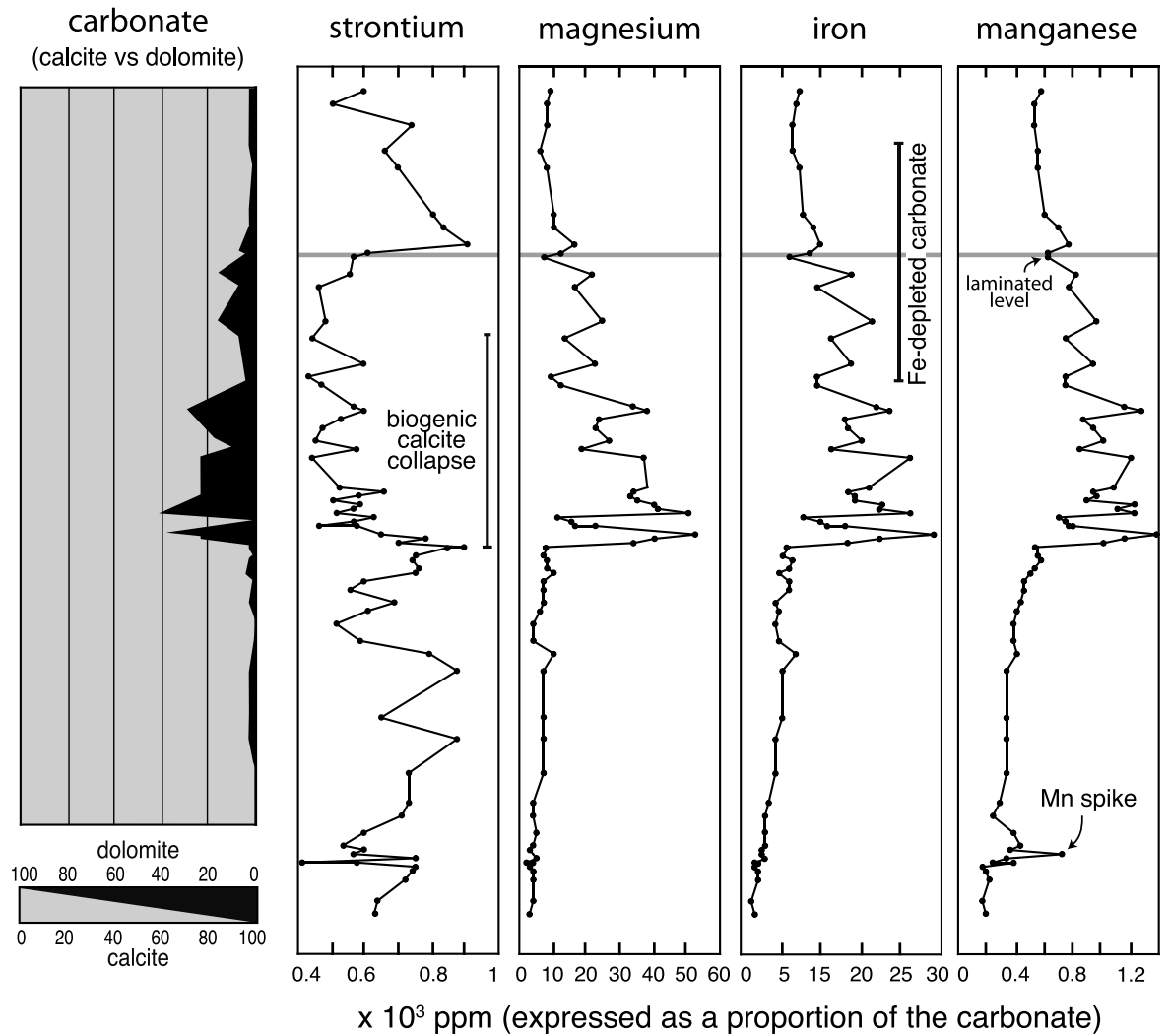

Figure 3. Comparison of the evolution of $\mathrm{C}$ isotope ratios in carbonate, calcite versus dolomite ratios expressed as relative fractions to the whole carbonate content, and metal ( $\mathrm{Sr}, \mathrm{Mg}, \mathrm{Fe}$, and $\mathrm{Mn}$ ) contents in carbonate. Gray boxes indicate the TOC content of the laminated intervals (for the gray scale, see Figure 1). (a) Sancerre (Paris Basin, France). (b) Peniche section (Lusitanian Basin, Portugal). 

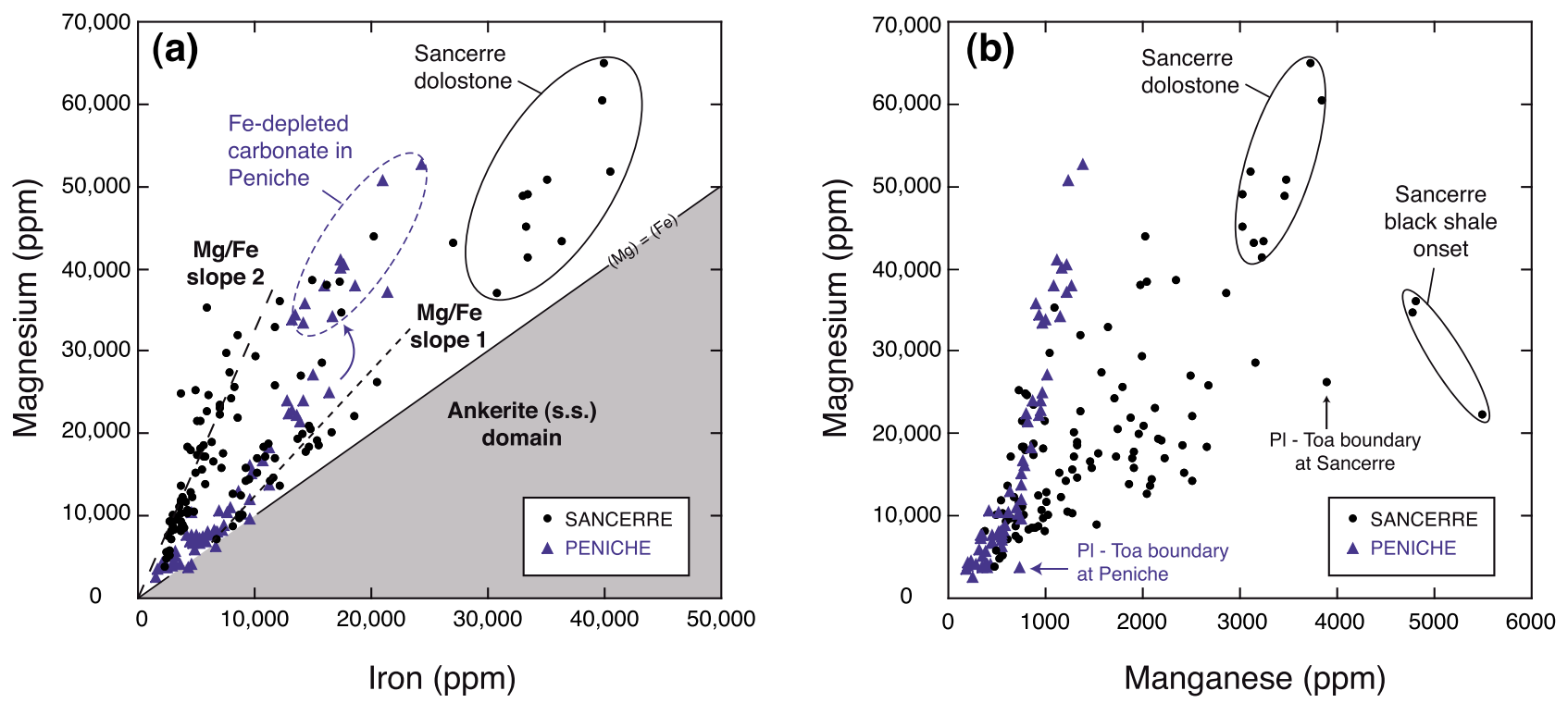

Figure 4. Relationship between (a) magnesium/iron and (b) magnesium/manganese in carbonates from Sancerre (black dots) and Peniche (blue triangles). The two different slopes $(\mathrm{Mg} / \mathrm{Fe}$ lines) observed in the $\mathrm{Mg} / \mathrm{Fe}$ correlations in the dolomite are explained by a relative iron depletion owing to previous $\mathrm{Fe}$ trapping by pyrite $\left(\mathrm{FeS}_{2}\right)$ precipitation $(\mathrm{Mg} / \mathrm{Fe}$ line 1 , low pyrite precipitation; $\mathrm{Mg} / \mathrm{Fe}$ line 2, substantive pyrite formation reflecting reducing conditions in seawater). Changes in the $\mathrm{Mg} / \mathrm{Fe}$ ratios in carbonate indicate the onset of reducing conditions in seawater and pore fluid in the upper part of Peniche section. Both lowermost Toarcian sediments in Sancerre and Peniche, and the first centimeters of the first black shale interval in Sancerre, display higher relative manganese contents in carbonate with respect to the whole $\mathrm{Mg} / \mathrm{Mn}$ correlation.

content, but a gradual increase in the abundance of elements continues up to about the $11 \mathrm{~m}$ level.

[23] At this level, corresponding to the sharp drop of the $\delta^{13} \mathrm{C}$ and the record of the first dolomite "spike," the magnesium and iron contents are significant, and reach their maximum values ( $\sim 55,000 \mathrm{ppm}$ for both elements). During the negative CIE interval, the concentrations are higher (fourfold) than background values and always follow the fluctuations in dolomite abundance.

[24] The upper part of the studied interval, in which the calcite fraction goes up, is marked by a progressive decrease in the content of both $\mathrm{Mg}$ and $\mathrm{Fe}$, but with values slightly higher than those observed stratigraphically below the negative CIE.

\subsection{Manganese}

[25] The overall evolution of manganese in Sancerre (Figure 3a) and Peniche (Figure 3b) follow trends described for magnesium and iron (Figures $4 \mathrm{a}$ and $4 \mathrm{~b}$ ). Nonetheless, Mn contents are significantly higher in Sancerre than in Peniche carbonates. For the two sections, regression coefficients ( $\mathrm{r}$ ) of the manganese are 0.70 with $\mathrm{Mg}$ and 0.73 with $\mathrm{Fe}$ in Sancerre, and 0.93 with $\mathrm{Mg}$ and 0.96 with $\mathrm{Fe}$ in Peniche. Nonetheless, several levels depart from this strong correlation such as the lowermost Toarcian marly sediments in both sections, where the $\mathrm{Mn}$ contents in carbonate are relatively high with respect to those of $\mathrm{Mg}$ and Fe. Measured $\mathrm{Mn}$ values are almost $4000 \mathrm{ppm}$ for Sancerre (Figure 3a) and $1400 \mathrm{ppm}$ for Peniche (Figure 3b).

[26] In Sancerre, another relative Mn-rich carbonate $(\sim 5000 \mathrm{ppm})$ level is developed at around $348.3 \mathrm{~m}$, i.e., the level of the stratigraphically lowest black shale interval. These high Mn values correspond to a threefold enrichment with respect to the overall $\mathrm{Mg} / \mathrm{Mn}$ correlation slope. The rest of this black shale as well as subsequent laminated intervals higher in this section (Figure 3a) are, however, not accompanied by such geochemical anomalies in the manganese content.

\subsection{Strontium \\ 4.4.1. Sancerre Core}

[27] The strontium contents measured in Sancerre are unexpectedly high, and so spot chemical analyzes using EDS-SEM were carried out throughout the whole studied interval to ensure that the strontium is contained in the carbonate lattice [Hermoso et al., 2007] and not in other phases. Neither sulfates nor aragonite nor other Sr-rich carbonates have been detected throughout the studied interval by this technique, and the $\mathrm{Sr}$ content in the calcite is sufficiently high to explain the elemental contents from the bulk carbonate.

[28] There is a progressive increase in the strontium content throughout the whole interval from 400 to $8500 \mathrm{ppm}$ (Figure 3a). This trend is more pronounced after the negative CIE. This positive trend is disrupted in the dolostone bed and at the level of the lowest black shale interval. In the first case, the drop in Sr content is likely explained by the very low incorporation of strontium in dolomite [Jacobson and Usdowski, 1976], whereas in the second case, such a dilution artifact by the dolomite is not observed, and a real decrease of strontium in calcite occurred. 
[29] The sharp increase of the $\delta^{13} \mathrm{C}$ that defines the recovery interval of the negative CIE is accompanied by an increase in the calcite content, and from $346 \mathrm{~m}$ by substantial Sr contents from 2000 to $8000 \mathrm{ppm}$. This level corresponds to a significant change in the calcareous nannofossil assemblage from Calyculus (living in the most surficial and low-nitrate waters [Mattioli et al., 2008]) toward Crepidolithus coccolithophores (a deeper dweller [Bour et al., 2007]) in Sancerre [Hermoso and Minoletti, 2008]. This nannofloral change seems to be a common biological feature at the scale of NW European basins [Mattioli et al., 2008]. The coincidence between this extraordinary $\mathrm{Sr}$ enrichment and the relatively great abundance of Crepidolithus above the level of the CIE has been tested by geochemical analyses performed at the carbonate particle level scale [Hermoso et al., 2007; Hermoso and Minoletti, 2008; Minoletti et al., 2009]. This coccolith has proven to be notably enriched in strontium with respect to other calcareous particles in the same assemblage such as Schizosphaerella calcispheres, other coccoliths and xenomorphic grains, which typically have lower $(<1000 \mathrm{ppm})$ strontium contents. The extremely high $\mathrm{Sr}$ content in the coccoliths of Crepidolithus is not found in the lowermost Toarcian sediments of Sancerre, but only in sediment deposited during the recovery from the CIE, where the $\mathrm{Sr}$ content in bulk carbonate is also high.

\subsubsection{Peniche Section}

[30] In the Peniche section, the maximum strontium contents of the carbonate do not exceed the background values of the Sancerre core. In the Lemede Fm, the strontium contents are $\sim 650 \mathrm{ppm}$ (Figure $3 \mathrm{~b}$ ). In the polymorphum Zone, the Sr contents of the gray marls vary between 500 and $700 \mathrm{ppm}$ with a minimum between $6 \mathrm{~m}$ to $9.5 \mathrm{~m}$. Above that, a $2 \mathrm{~m}$ thick interval records a rapid increase, leading to the maximal Sr content of the section ( $~ 900 \mathrm{ppm})$. This level is located stratigraphically below the dolomite-enriched interval and the onset of the negative CIE.

[31] At the level of a large decrease in $\delta^{13} \mathrm{C}$ values at about $11 \mathrm{~m}$, the $\mathrm{Sr}$ content drops and remains relatively low with a weak decrease during the whole CIE interval. This $\mathrm{Sr}$ decrease can be only partly assigned to a dilution effect due to enhanced dolomite content; consequently, the Sr contents in calcite effectively record a decrease throughout the negative CIE.

[32] Where both total carbonate content and $\delta^{13} \mathrm{C}$ increase again at the $19.5 \mathrm{~m}$ level, the strontium content in the carbonate also rises to $850 \mathrm{ppm}$. However, at $22 \mathrm{~m}$, another $\mathrm{Sr}$ decrease is observed, which is not reflected in the $\delta^{13} \mathrm{C}$ data. This negative trend is maintained up to the top of the studied interval.

[33] Even if absolute $\delta^{13} \mathrm{C}$ values are different in Peniche compared with Sancerre, similar trends in Sr content occur through both CIEs, virtually parallel to the calcite content, particularly during the negative excursion.

\section{Redox State of the Water Column Through the CIE}

[34] The calcite versus dolomite content in the two sections, in particular through in the negative CIE intervals, is different. A dolostone was formed prior to both black shale intervals and accompanying the negative CIE in Sancerre, whereas in Peniche, proportions of dolomite are higher than background levels within the CIE.

[35] The presence of dolomite is common in Jurassic deposits, particularly those formed in oxygen-depleted environment [Michard, 1960; Irwin et al., 1977; Hanzo et al., 2000]. The expression of a Mg-rich carbonate phase in the sediment mostly depends on the sulfate concentration in pore fluid and its $\mathrm{Mg} / \mathrm{Ca}$ ratio. Because sulfate ions preclude the incorporation of magnesium into carbonate $(\mathrm{Mg}-$ $\mathrm{SO}_{4}$ bond), the precipitation of dolomite occurs when sulfates have been removed from pore fluids by the formation of evaporite species or bacterial reduction and incorporation into sulfides such as pyrite. In the two sections investigated here, dolomite is present as rhombohedra displaying only limited dissolution. This good preservation, unlike the calcareous nannofossils that exhibit enhanced dissolution features, suggests that they are not of detrital origin. The formation of this dolomite in Sancerre Jurassic deposits has been ascribed to an early diagenetic process [Mélières, 1991; Hermoso et al., 2009] based on textural, morphological and mineralogical arguments. Comparable dolomite is observed in modern dysoxic environments of the Peru margin [Meister et al., 2007] and is similarly attributed to very early diagenetic precipitation. Additionally, both carbon and oxygen isotope signatures of the dolomitic phase are relatively close to those of the biogenic calcite in the Sancerre core [Hermoso et al., 2009], which supports an early precipitation in the sediment, unlike those phases with low $\delta^{13} \mathrm{C}$ values that derived from the oxidation of organic matter [Irwin et al., 1977].

\subsection{Mg/Fe Ratio in Carbonate Reveals Redox Conditions in Pore Fluids}

[36] The strong covariation between relative dolomite content, and measured magnesium and iron content (Figures 3 and 4), indicates that these ions are chiefly located in the dolomite lattice. These elements mostly derive from continental weathering and, in the case of iron, are carried in the form of oxyhydroxides on clay minerals by the river into seawater [Carroll, 1958]. Given that iron has distinct redoxsensitive speciation in seawater (e.g., $\mathrm{Fe}^{3+}$ and $\mathrm{Fe}^{2+}$ ), even if the flux from the continent is constant, coprecipitation into carbonate depends on the balance between oxidized versus reduced ions, which is driven by the redox state of the pore fluid in which the dolomite precipitates. Although magnesium is less sensitive to dysoxic/anoxic conditions than is iron, increases in both these two elements in carbonate from the lowest Toarcian strata could be regarded as an oxic to dysoxic progression. When seawater became euxinic, sulfate reduction fixed iron as pyrite in framboids within the water column [Karlin and Levi, 1983; Wilkin and Barnes, 1997], whereas magnesium, less sensitive to redox change, was still incorporated in carbonate.

[37] The differences in the $\mathrm{Mg} / \mathrm{Fe}$ ratio recorded in Sancerre at the base of the dolostone and further up in the core $(\mathrm{Mg} / \mathrm{Fe}$ lines 1 and 2 in Figure $4 \mathrm{a})$ would require irregularity in supply to the site of reaction or, assuming a 
(a) SANCERRE

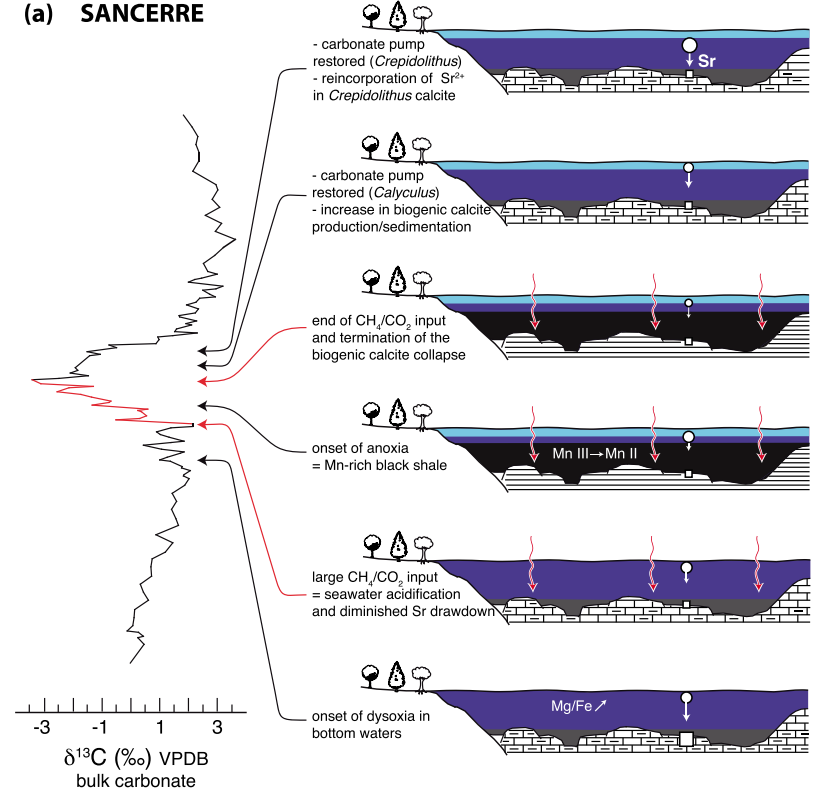

(b) PENICHE

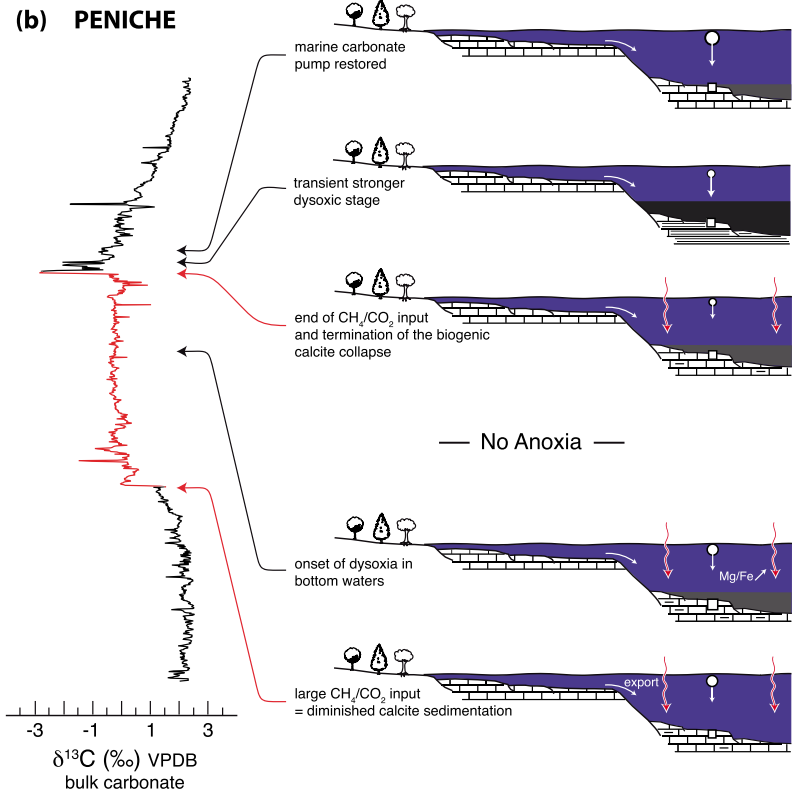

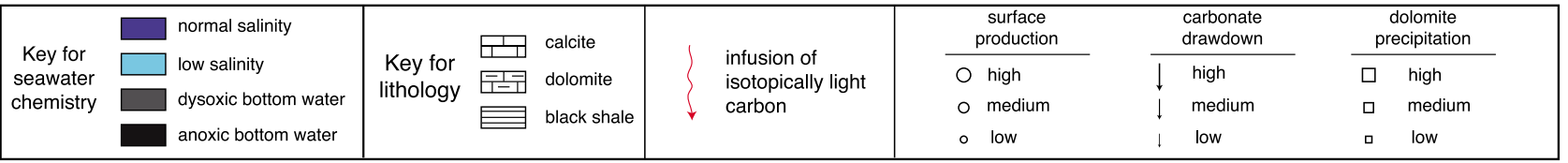

Figure 5. Evolution of seawater chemistry and the carbonate productivity/drawdown across the negative carbon isotope excursion in the two studied basins. (a) Paris Basin, Sancerre (France). The negative CIE occurred through a long-term dysoxic-anoxic transition and is accompanied by a drop in the biogenic calcite content. Black shales are observed at the second step of the negative $\mathrm{C}$ isotope shift and associated with a notable $\mathrm{Mn}$ spike in carbonate. A salinity stratification of the water column is developed, which persisted during the rest of the T-OAE. After the end of the $\delta^{13} \mathrm{C}$ negative shift, the carbonate pump was rapidly restored, and also associated with very high $\mathrm{Sr} / \mathrm{Ca}$ ratio in the sediment when the abundance of the Crepidolithus crassus coccolithophore became significant. (b) Lusitanian Basin, Peniche (Portugal). The $\delta^{13} \mathrm{C}$ negative shift is the first geochemical event recorded through the section, and it is also accompanied by lowered calcite particle drawdown and higher dolomite content. Dysoxic conditions deduced by higher $\mathrm{Mg} / \mathrm{Fe}$ ratio in carbonate were initiated during the CIE plateau without any corresponding change in the carbon isotope profile. Both calcite content and $\mathrm{Sr} / \mathrm{Ca}$ ratio increase at the termination of the low $\delta^{13} \mathrm{C}$ interval. A thin organic-rich mudstone (TOC $\sim 2.6 \%$; HI $\sim 320 \mathrm{mg} \mathrm{HC} / \mathrm{g} \mathrm{TOC}$ ) is recorded in this recovery interval, which is associated neither with lowest $\mathrm{C}$ isotope values in carbonate nor with high $\mathrm{Mn}$ concentrations.

constant ratio in the supply of these two elements, an additional mineralogical trap for either iron or magnesium prior to dolomite formation. In Sancerre, a shift indicating relative Fe depletion with respect to $\mathrm{Mg}$ is observed from the base of the dolostone up to the top of the studied interval and corresponds to the level with substantial presence of framboidal pyrite (about $5 \mu \mathrm{m}$ in diameter) in the sediment [Hermoso et al., 2009]. This syngenetic pyrite is comparable in size to those observed in the Lower Toarcian from Yorkshire. Such a form of pyrite precipitated at the oxic/ dysoxic boundary within the water column [Wilkin et al., 1996] has been used for indicating euxinic conditions in seawater [Wilkin and Barnes, 1997; Bellanca et al., 1999; Wignall et al., 2005]. Thus, these euxinic conditions recorded by enhanced pyrite formation are accompanied by an offset toward lower Fe concentration in pore fluid, as recorded in dolomite (Figures $4 \mathrm{a}$ and 5a). In Peniche, such a shift toward lower iron concentrations in carbonate (Figures $3 \mathrm{~b}$ and $4 \mathrm{a}$ ) is also observed, between $17 \mathrm{~m}$ and $25 \mathrm{~m}$.

\subsection{Mn Spikes Indicate Termination of Oxygen Availability in the Water Column}

[38] The strong correlation between $\mathrm{Fe}$ and $\mathrm{Mg}$, but also with $\mathrm{Mn}$ measured in the two locations, indicates a common mineral lattice for these three elements by the coprecipitation of $\mathrm{Mn}$ into a Mg-rich carbonate, namely the dolomite [Böttcher, 1998; Bellanca et al., 1999]. Because manganese in seawater is present in distinct oxidation states $\left(\mathrm{Mn}^{4+} /\right.$ $\mathrm{Mn}^{3+}$ and $\mathrm{Mn}^{2+}$ incorporated into oxyhydroxides and carbonates, respectively), the substitution of manganese into the calcite or dolomite lattice forming at or just below the seafloor can take place under certain redox conditions. 
Condensed intervals related to maximum flooding surfaces may be characterized by high $\mathrm{Mn}$ contents in carbonate [Emmanuel and Renard, 1993; Jarvis et al., 2001]. In the present study, transitions between both the Lemede Fm and the Cabo Carvoeiro Fm in Peniche, and the Grès médioliasiques Fm and Schistes carton Fm in Sancerre (slightly postdating the Pliensbachian/Toarcian boundary in the two cases) are accompanied by high manganese contents (Figures $4 \mathrm{a}$ and $4 \mathrm{~b}$ ). This lithological change record sedimentary condensation, as is also suggested by notable accumulations of belemnite rostra. A condensed interval around the Pliensbachian/Toarcian boundary has been previously proposed on a west European scale in the work by Morard et al. [2003], which may be attributed to a maximum flooding surface sensu Haq et al. [1988] and Hallam [1997]. Major paleoenvironmental changes have been inferred for this earliest Toarcian interval in Peniche because this level records a $\sim-2 \%$ negative $\delta^{13} \mathrm{C}$ excursion in bulk carbonate (Figure 3b) [Hesselbo et al., 2007], and a concomitant $\sim-1.5 \%$ negative shift $\delta^{18} \mathrm{O}$ in brachiopod calcite [Suan et al., 2008b]. In southern France, the Quercy Basin (Penne section) also records a negative CIE around the Pliensbachian/ Toarcian boundary [Emmanuel et al., 2006]. This first carbon isotope perturbation accompanying the Mn spike is, however, not recorded in Sancerre. Further work is required in boreal realms to determine the regional extent of this event and further our knowledge about the nature of this change of the seawater chemistry at the Pliensbachian/ Toarcian boundary, which may correspond to a major pulse of volcanism in the Karoo Large Igneous province [Jourdan et al., 2008; Moulin et al., 2008].

[39] Subsequently during the Early Toarcian, the evolution of facies in neither locations suggest strong condensation, and the short-term fluctuation in the $\mathrm{Mn}$ in carbonate may be related to redox-sensitive effects [Huckriede and Meischner, 1996], as previously applied for Toarcian black shales [Jenkyns, 1985; Jenkyns et al., 1991; Vetö et al., 1997; Ebli et al., 1998; Bellanca et al., 1999; Jenkyns et al., 2002; Emmanuel et al., 2006]. The mechanism explaining the response of manganese to redox change relies on the high sensitivity of manganese to the redox state of the environment when compared with to iron and magnesium. When the environment shifted from relatively poorly oxygenated water toward strongly anoxic conditions leading to black shale deposition, oxide and hydroxide phases were destabilized and dissolved: $\mathrm{Mn}^{4+} / \mathrm{Mn}^{3+}$ species reduced to $\mathrm{Mn}^{2+}$, and then incorporated into the carbonate lattice, thus explaining the redox-driven Mn spike in the geochemical record.

[40] The inception of the first black shale interval in Sancerre is accompanied by such a pronounced Mn spike related to redox change in the water column and in pore fluids. At this level, a supplementary source of manganese provided by oxide removal explains the relative Mn enrichment in carbonate that departs from the correlation with magnesium and iron (Figure 5b). Hence, the difference in $\mathrm{Mg} / \mathrm{Fe} / \mathrm{Mn}$ correlation and the presence of the $\mathrm{Mn}$ spike at the base of the black shale in Sancerre records the inception of strong anoxia in the water column and in the interstitial sediment (Figure 5a).
[41] The absence of clear laminations and presence of bioturbation through most of the Peniche section rules out the development of totally anoxic conditions, as remarked upon by McArthur et al. [2008a]. Nevertheless, a thick interval from $17.5 \mathrm{~m}$ up to $26 \mathrm{~m}$ with weakly developed sedimentary lamination evidences broadly dysoxic conditions in pore fluids, at least in bottom waters over the interval characterized by the negative CIE and above (Figures $3 \mathrm{~b}$ and $5 \mathrm{~b}$ ). A Mn spike is, however, not recorded in Peniche in these partly laminated facies. The absence of such $\mathrm{Mn}$ enrichment in carbonate indicates that oxygen deficiency was not intense enough to introduce divalent Mn into the environment in Peniche.

\subsection{Contrasts in the Record of Dysoxia, Anoxia, and CIE in Both Sections}

[42] Comparing both sections, it is apparent that the evolution of the redox state of the water column is independent of the CIE. In Sancerre, the first step of the $\delta^{13} \mathrm{C}$ decrease occurred at a level below that of the lowest black shale of the OAE. This setting indicates that the establishment of reducing bottom water is unrelated to the onset of the $\delta^{13} \mathrm{C}$ negative shift. On a longer time scale, it is only the stratigraphically lowest black shale interval in Sancerre that is associated with a $-6 \%$ negative CIE. After the negative CIE recorded in Paris Basin, further evidence of anoxic conditions is displayed in the sediments, which are not accompanied by unusually low carbon isotope values. In Peniche, no stratigraphically extensive black shale facies is expressed, although geochemical evidence deduced from the $\mathrm{Mg} / \mathrm{Fe}$ ratio in carbonate, by analogy with Sancerre, indicates reducing conditions in seawater within the negative CIE, and these were maintained during and after the recovery interval. Nevertheless, the geochemical signature of this redox change does not coincide with the steps in the $\delta^{13} \mathrm{C}$ decrease as would be expected if these two geochemical events were linked.

[43] The change in flux rate of the organic carbon sinking through the water column is a key parameter for understanding the $\delta^{13} \mathrm{C}$ depth profile during the Early Toarcian, but it is difficult to discuss the extent to which the emission of $\mathrm{CH}_{4}$ into the atmosphere has participated in the consumption of oxygen during its oxidation into $\mathrm{CO}_{2}$, as suggested by Emmanuel et al. [2006]. The fact that the relationship between the CIE and the T-OAE records, as defined by the stratigraphical distribution of organic-rich shales, is not identical in all European sections, suggests that the onset of the anoxia, regardless of the negative CIE, was under local/regional control, as suggested by McArthur [2007] and McArthur et al. [2008a, 2008b]. Such a conclusion does not, however, rule out the hypothesis that an increase in organic productivity was globally synchronous and was the principal causative factor behind the T-OAE.

\section{Efficiency of the Carbonate Pump Through the CIE}

[44] $\mathrm{The} \mathrm{Sr} / \mathrm{Ca}$ ratio has been widely used as a paleoproductivity proxy since the work of Stoll and Schrag [2000] and Rickaby et al. [2002]. For the Early Toarcian critical 
interval, two distinct parameters need to be considered for understanding how the carbonate pump evolved: the surface productivity itself and the sedimentation and preservation of secreted biogenic calcite particles. The strontium concentrations in the Sancerre carbonates are particularly high when compared with typical Jurassic pelagic carbonates, especially in the upper part of the section where values reach $4000 \mathrm{ppm}$. Typical strontium contents in pelagic sediments are generally less than 1000 ppm [Renard, 1986], which is the limit of values for the Peniche section. Using an average partition coefficient of strontium into the calcite lattice $\left(\mathrm{K}_{\mathrm{Sr}} \sim 0.13\right.$ [Kinsman, 1969]) and dolomite $\left(\mathrm{K}_{\mathrm{Sr}} \sim 0.07\right.$ [Jacobson and Usdowski, 1976]), it appears that the unusually high strontium content in Sancerre carbonate cannot be ascribed to precipitation from normal $(\sim 10 \mathrm{ppm}$ Sr) seawater. Primary aragonite (a relatively high Sr carbonate phase) mineralogy of the coccolith specimens of this section is ruled out, given their preservational state [see Hermoso et al., 2009, Figure 4b]. In addition, diagenesis is known to be responsible for decreasing the strontium contents in marine carbonates [Richter and Liang, 1993]. Thus, the measurements of strontium in Sancerre require either an unrealistically high $\mathrm{K}_{\mathrm{Sr}}$ (up to 0.5 ) and/or extraordinarily high concentrations of this element in seawater (up to $150 \mathrm{ppm}$ ).

[45] Langer et al. [2006] have cultured Emiliania huxleyi under doped $\mathrm{Sr} / \mathrm{Ca}$ media concentrations in laboratory experiments. This study demonstrates that this modern coccolith can incorporate high amounts of strontium $(\mathrm{Sr} / \mathrm{Ca} \sim$ $35 \mathrm{mmol} / \mathrm{mol}$ ) mineralized from $\mathrm{Sr} / \mathrm{Ca}$ of the media $\sim 90 \mathrm{mmol} / \mathrm{mol}$, corresponding to a partition coefficient of strontium into calcite about 0.39. Taken together, these observations indicate that such high strontium contents in a biogenic phase are possible and may chiefly depend on $\mathrm{Sr} / \mathrm{Ca}$ ratio in seawater.

\subsection{Biogenic Calcite and Strontium Contents During the $\delta^{13} \mathrm{C}$ Decrease Interval}

[46] In both studied sections, the relative decreases in the calcium carbonate content in the CIE intervals are also associated with decreases in the strontium content (Figures 2a and $2 \mathrm{~b}$ ). This relationship could be linked to a lowered carbonate production in surface water and/or a decrease of the carbonate drawdown to the seafloor (Figures 5a and 5b). It is hence important to assess the respective contributions of a decrease in calcium carbonate productivity and/or sedimentation to explain this interval of low biogenic calcite content characterized by lowered $\mathrm{Sr}$ content in calcium carbonate.

[47] Calculated calcareous nannoplankton fluxes in various European sections indicate depressed nannofossil accumulation rate to the seafloor over the CIE interval [Mattioli et al., 2008, 2009]. In contrast, large-scale deposition of phytoplanktonic organic matter indicates that primary productivity remained very high during the T-OAE. Although other organisms have also contributed to the primary production [Jenkyns et al., 2001], especially in the western Tethys [Bucefalo-Palliani et al., 2002; Tremolada et al., 2005], the organic production by calcareous nannoflora did remain locally dominant, at least in NW Europe [Hollander et al., 1991]. Hence, a mechanism to decouple carbonate and organic matter production needs to be sought. One possibility is acidification, related to massive $\mathrm{CO}_{2}$ injection into seawater during the period of $\delta^{13} \mathrm{C}$ decrease [Hesselbo et al., 2000; Mattioli et al., 2004]. Not only could this perturbation of seawater alkalinity have induced a dissolution of carbonate on the seafloor, but it may also have contributed to the decrease of carbonate surface productivity, as demonstrated by marine calcifier culturing experiments [Riebesell et al., 2000; Rost and Riebesell, 2004]. Both features seem to be similarly recorded with the onset of the negative CIE for both locations in the present study (Figures $5 \mathrm{a}$ and $5 \mathrm{~b}$ ).

[48] During the CIE, not only was less biogenic calcite produced and preserved in both locations, but also the calcareous nannoplankton was dominated by the Calyculus coccolithophore, know to mineralize from surface brackish waters [Mattioli et al., 2008]: a relevant observation in the context of proposed enhanced fresh water supply during this period [Cohen et al., 2004; Dera et al., 2009]. The low Sr content of these brackish waters could explain the lowered strontium contents in the biogenic calcite produced during the negative CIE. The independent evolution of Sr monitored by the coccolithophores at the top of the water column, compared with the increasing Sr contents $(\sim \times 1.6$ with respect to $\mathrm{Ca}$ ) of the belemnites throughout the T-OAE [McArthur et al., 2000; Bailey et al., 2003] implies a clear chemical stratification of the water column.

\subsection{Recovery Interval in a Relatively Restricted Environment (Paris Basin)}

[49] In the NW European seaway, there is evidence for stratification of water masses during the T-OAE with lower salinity conditions prevailing in the most surficial body mass [Farrimond et al., 1989; Wignall et al., 2005; McArthur et al., 2008a] that were detrimental for the calcareous nannoflora [Mattioli et al., 2008]. In NW Europe, this water column stratification may in part be recorded by a $\sim-1.5 \%$ negative shift in the $\delta^{18} \mathrm{O}$ evolution in coccolith-bearing carbonates (Figure 2a and supplementary data in the work by Hermoso et al. [2009]), and belemnites [Bailey et al., 2003] at the beginning of black shale deposition. However, it is likely that an increase in seawater temperature, coincident with a suggested rise in $\mathrm{COO}_{2}$ levels [McElwain et al., 2005], also imprinted the $\delta^{18} \mathrm{O}$ record. Also, the osmium isotope profile from coeval black shales in Yorkshire is interpreted to represent a significant increase in weathering and hence fresh water input into the basin [Cohen et al., 2004]. At the termination of the $\delta^{13} \mathrm{C}$ decrease (defining the beginning of the recovery interval), the increase in \%wt. biogenic calcite indicates that the efficiency of the marine carbonate pump was restored. When the nannofloral assemblage shifted from Calyculus dominated toward Crepidolithus dominated (transition recorded at $\sim 346 \mathrm{~m}$ in Sancerre [Hermoso and Minoletti, 2008]), the strontium content in calcium carbonate increased dramatically (Figures $3 \mathrm{a}$ and 5a). This geochemical event may be explained by their different living depths within the water column: Calyculus thrived at the top of the water column in a lowered salinity zone [Mattioli et al., 2008], probably depleted in strontium, 
whereas Crepidolithus crassus, a deep dweller [Bour et al., 2007], calcified at greater depths from normal salinity seawater with higher $\mathrm{Sr}$ concentrations that were 5-10 times greater than that of modern seawater. We argue that an accumulation of restricted basin $\mathrm{Sr}$ concentrations occurred during the $\delta^{13} \mathrm{C}$ decrease as a result of the biogenic calcite collapse and/or lack of aragonite deposition owing to the acidification stage. At the end of the event, this excess $\mathrm{Sr}$ of these regions was incorporated into both deeper dwelling coccoliths (Figure 5a) and belemnites [McArthur et al., 2000; Bailey et al., 2003].

[50] The nature of the very high primary productivity and the concomitant unusually high $\mathrm{Sr} / \mathrm{Ca}$ incorporation in coccolithophore calcite during the recovery interval are still poorly understood. It is interesting to speculate that the coccolithophores could have acted as a feedback on the global carbon cycle due to massive $\mathrm{CO}_{2}$ drawdown. Previous works have attempted to underline similarities between the Toarcian events and the Paleocene/Eocene Thermal Maximum [Cohen et al., 2007; Mattioli et al., 2009]. For the PETM, it has been proposed that the reestablishment of the marine carbonate pump after the CIE was relatively efficient in proximal sites compared with the open marine realm [Gibbs et al., 2006]. The demonstration of such a contrast between epicontinental versus oceanic realms for the Toarcian event would require a larger scale picture of these biogeochemical changes. However, the apparent complete subduction of Early Jurassic oceanic seafloor precludes access to an Early Toarcian record of open oceanic conditions. Nevertheless, the higher productivity in the epicontinental seas may have been the result of increased continental weathering, as suggested by the osmium isotope profile [Cohen et al., 2004] forced by high $p \mathrm{CO}_{2}$ levels [McElwain et al., 2005], and thus significant basinward nutrient supply. It seems likely that enhanced continental discharge was the foremost mechanism that helped to reestablish seawater alkalinity and carbonate preservation after the Early Toarcian CIE.

\subsection{Recovery Interval in a More Open Marine Realm (Lusitanian Basin)}

[51] The strontium contents in the carbonate of Sancerre and Peniche are similar in the Late Pliensbachian interval, but in the Early Toarcian section, particularly in sediments postdating the negative CIE, the contents are significantly lower in Peniche than in Sancerre. Furthermore, the $\mathrm{Sr} / \mathrm{Ca}$ lower ratios in Peniche carbonate during the CIE (Figure 3b) are exaggerated by a higher dolomite content (low Sr phase). The nannofloral change observed in the Paris Basin during the recovery interval is not clearly illustrated in the Peniche section, as noted in the work of Mattioli et al. [2008], and the abundance of Crepidolithus after the CIE remained low, which could also explain the relatively limited $\mathrm{Sr}$ content in Peniche with respect to the more restricted environments from NW Europe. Additionally, there is no geochemical evidence for seawater stratification in the Lusitanian Basin: the oxygen isotope profile from bulk carbonate does not display any negative shift (Figure $2 \mathrm{~b}$ and supplementary data in the work by Hesselbo et al. [2007]) that might indicate fresh water supply during the Early Toarcian interval, as is the case in the Paris Basin. Furthermore, the Lusitanian Basin represents a more open-marine realm with easier interchange with Tethyan waters than the various basins of the NW European epicontinental seaway. Although a relatively elevated $\mathrm{Sr}$ content is observed in Peniche in the recovery interval above the negative CIE, it is unlikely that there was any exceptional accumulation of this element throughout the times of the T-OAE in this basin, probably because the accumulated strontium was mixed with more open marine seawater.

[52] The difference in the structure of the water column between the Lusitanian and the Paris Basins is consistent with the idea that the seawater stratification was, at least partly, controlled by low-salinity water discharges coming from the Arctic region via the transcontinental Laurasian seaway [Bjerrum et al., 2001], as proposed in the study by Mattioli et al. [2009]. This southward flux could have conceivably had less influence in the westernmost Tethyan realm than in the restricted NW European epicontinental seas (Figure 1). Because it was located at the junction between the westernmost Tethys and the Proto-Atlantic (Figure 1), the Lusitanian Basin can be regarded as a more open marine environment with respect to the Paris Basin. Again, by analogy with the PETM, the relatively low productivity in Peniche is in agreement with the proximal/ distal gradient in productivity of the PETM demonstrated by Gibbs et al. [2006]. Taken together, this corroborates a common biogeochemical gradient in the drawdown of excess $\mathrm{CO}_{2}$ after the Early Toarcian and PETM negative CIEs with a maximal efficiency of the "biological pump" in shelf sea environments.

\section{Conclusion}

[53] Seawater in the Paris Basin throughout the Early Toarcian experienced progressive oxygen depletion from dysoxic toward anoxic/euxinic conditions leading to the deposition of black shales. Although a globally synchronous increase in organic productivity may have triggered the T-OAE, it appears that the onset of anoxia was eventually forced by local factors such as basinal restriction and seawater stratification. The fact that the negative CIE occurred before the onset of anoxia rules out the explanation involving upwelling of ${ }^{12} \mathrm{C}$-rich to surface waters in a highly stratified water column, as originally proposed by Küspert [1982]. The Early Toarcian pronounced $\delta^{13} \mathrm{C}$ decrease is better accounted for by a global model such as methane hydrate dissociation as proposed by Hesselbo et al. [2000] with effects on the seawater alkalinity, and thus carbonate productivity and preservation. This supposed massive emission of methane, fingerprinted by the low $\delta^{13} \mathrm{C}$ ratios in carbonate, slightly predated the development of regional anoxia (highlighted by a pronounced Mn spike in the geochemical record) in the southern Paris Basin. This chronology may indicate local participation of oxygen consumption by methane reduction as a forcing function for the onset of anoxia. That this negative CIE is independent of the local physicochemistry of seawater is also illustrated in the Lusitanian Basin, where dysoxic conditions in bottom waters clearly postdated the onset of the negative 
shift. The absence of fully anoxic conditions may be explained by a low in situ primary productivity, and a more oxygenated environment due to seawater exchanges with the open oceanic realm.

[54] The carbonate pump evolved similarly in both studied environments with depressed biogenic calcite content through the $\delta^{13} \mathrm{C}$ decrease, as suggested by the work of Mattioli et al. [2009]. Although this observation from both studied locations may result from lowered surface productivity, it is likely that seawater acidification, induced by $\mathrm{CH}_{4} / \mathrm{CO}_{2}$ release, led to diminished calcium carbonate drawdown through the water column. However, this event does not explain the concomitant relatively low strontium content in the biogenic calcite (coccoliths) from the Paris Basin. This $\mathrm{Sr} / \mathrm{Ca}$ depression is not directly linked to low productivity setting in surface waters, but is better explained by the coccolithophorid assemblage that was strongly influenced by fresh water inputs in the context of elevated $p \mathrm{CO}_{2}$ levels [Cohen et al., 2004; McElwain et al., 2005; Dera et al., 2009] and/or Arctic fresh water discharge [Bjerrum et al., 2001], especially in NW Europe. Thus, an increase in the strontium concentration in seawater may have resulted from the acidification stage by reduced removal of this element from seawater in the biogenic calcite and/or in aragonite. This "geochemical anomaly" is recorded through the T-OAE in the belemnite calcite from Yorkshire [Bailey et al., 2003] and during the recovery interval, as soon as the nannofloral assemblage changed to deeper dwellers (mostly Crepidolithus crassus) calcifying from normal salinity waters in the Paris Basin. In contrast, in the Lusitanian Basin, which was more exposed to oceanic water masses of the Proto-Atlantic and the western Tethys, limited productivity operated during the recovery interval and the $\mathrm{Sr} / \mathrm{Ca}$ ratio in calcium carbonate did not rise so significantly compared to NW European seas.

[55] Acknowledgments. The authors thank the technical support of the JE2477 at University Pierre et Marie Curie (Paris 6) for the help in the preparation of the samples and in the clean laboratory for elemental analyses. Samples from the Sancerre core (GPF) were kindly provided by the Bureau des Recherches Géologiques et Minières via Bruno Galbrun. We thank Eelco Rohling for handling the manuscript, Thomas Algeo and an anonymous referee for their scientific critiques. MH and LE acknowledge the CNRS Research Program ECLIPSE II, and especially Pascal Neige who provided funding for the fieldwork in Peniche in 2005. MH was supported by the Fonds National de la Recherche de Luxembourg through BFR02/058 (Ph.D. in Paris) and AFR-08-002 (Postdoc in Oxford) fellowships, and FM by a UPMC action (BQR2006)

\section{References}

Bailey, T. R., Y. Rosenthal, J. M. McArthur, B. van de Schootbrugge, and M. F. Thirlwall (2003), Paleoceanographic changes of the Late Pliensbachian-Early Toarcian interval: A possible link to the genesis of an oceanic anoxic event, Earth Planet. Sci. Lett., 212, 307-320, doi:10.1016/S0012-821X(03)00278-4.

Bassoullet, J.-P., and F. Baudin (1994), Le Toarcien inférieur: Un période de crise dans les bassins et sur les plates-formes carbonatées de l'Europe du nord-ouest et de la Téthys, Geobios, 27, 645-654, doi:10.1016/S00166995(94)80227-0.

Bassoullet, J.-P., S. Elmi, A. Poisson, F. Cecca, Y. Bellion, R. Guiraud, and F. Baudin (1993), Middle Toarcian (184-182 Ma), in Atlas Tethys Palaeoenvironmental Maps, edited by J. Dercourt, L. E. Ricou, and B. Vrielynck, pp. $63-80$, BECIP-FRANLAB, RueilMalmaison, France.

Baudin, F., J.-P. Herbin, J.-P. Bassoulet, J. Dercourt, G. Lachkar, H. Manivit, and M. Renard (1990), Distribution of organic matter during the Toarcian in the Mediterranean Tethys and Middle East, AAPG Stud. Geol., 30, 73-91.

Bellanca, A., D. Masetti, R. Neri, and F. Venezia (1999), Geochemical and sedimentological evidence of productivity cycles recorded in Toarcian black shales from Belluno Basin, Southern Alps, northern Italy, J. Sediment. Res., 69, 466-476.

Bernoulli, D., and H. C. Jenkyns (2009), Ancient oceans and continental margins of the AlpineMediterranean Tethys: Deciphering clues from Mesozoic pelagic sediments and ophiolites, Sedimentology, 56, 149-190, doi:10.1111/ j.1365-3091.2008.01017.x.

Bjerrum, C. J., F. Surlyk, J. H. Callomon, and R. L. Slingerland (2001), Numerical paleoceanographic study of the Early Jurassic transcontinental Laurasian Seaway, Paleoceanography, 16, 390-404, doi:10.1029/2000PA000512.

Böttcher, M. E. (1998), Manganese (II) partitioning during experimental precipitation of rhodochrosite-calcite solid solutions from aqueous solutions, Mar. Chem., 62, 287-297, doi:10.1016/S0304-4203(98)00039-5.

Bour, Y., E. Mattioli, and B. Pittet (2007), Nannofacies analysis as a tool to reconstruct paleoenvironmental changes during the Early Toarcian anoxic event, Palaeogeogr. Palaeoclimatol. Palaeoecol., 249, 58-79, doi:10.1016/ j.palaeo.2007.01.013.

Bucefalo-Palliani, R., E. Mattioli, and J. B. Riding (2002), The response of marine phytoplankton and sedimentary organic matter to the Early Toarcian (Lower Jurassic) oceanic anoxic event in northern England, Mar. Micropaleontol., 46, 223-245, doi:10.1016/S0377-8398(02) 00064-6.

Carroll, D. (1958), Role of clay minerals in the transportation of iron, Geochim. Cosmochim. Acta, 14, 17-28, doi:10.1016/0016-7037(58) 90090-5.

Cohen, A. S., A. L. Coe, S. M. Harding, and L. Schwark (2004), Osmium isotope evidence for the regulation of atmospheric $\mathrm{CO}_{2}$ by continental weathering, Geology, 32, 157-160, doi:10.1130/G20158.1.

Cohen, A. S., A. L. Coe, and D. B. Kemp (2007), The late Paleocene-early Eocene and Toarcian (Early Jurassic) carbon isotope excursions: A comparison of their timescales, associated environmental changes, causes and consequences, J. Geol. Soc., 164, 1093-1108, doi:10.1144/0016-76492006-123.

Dera, G., E. Pucéat, P. Pellenard, P. Neige, D. Delsate, M. M. Joachimski, L. Reisberg, and M. Martinez (2009), Water mass exchange and variations in seawater temperature in the NW Tethys during the Early Jurassic: Evidence from neodymium and oxygen isotopes of fish teeth and belemnites, Earth Planet. Sci. Lett., 286, 198-207, doi:10.1016/j.epsl.2009. 06.027 .

Duarte, L. V. (1997), Facies analysis and sequential evolution of the Toarcian-Lower Aalenian series in the Lusitanian Basin (Portugal), Comun. Inst. Geol. Min., 83, 65-94.

Duncan, R. A., P. R. Hooper, J. Rehacek, J. S. Marsh, and A. R. Duncan (1997), The timing and duration of the Karoo igneous event southern Gondwana, J. Geophys. Res., 102, 18,127-18,138, doi:10.1029/97JB00972.

Ebli, O., I. Vetö, H. Lobitzer, C. Sajgó, A. Demény, and M. Hetényi (1998), Primary productivity and early diagenesis in the Toarcian Tethys on the example of the Mn-rich black shales of the Sachrang Formation, Northern Calcareous Alps, Org. Geochem., 29, 1635-1647, doi:10.1016/S0146-6380(98)00069-2.

Elmi, S. (2006), Pliensbachian/Toarcian boundary: The proposed GSSP of Peniche (Portugal), Volumina Jurassica, 4, 5-16.

Emmanuel, L., and M. Renard (1993), Carbonate geochemistry $\left(\mathrm{Mn}, \delta^{13} \mathrm{C}, \delta^{18} \mathrm{O}\right)$ of the Late Tithonian-Berriasian pelagic limestones of the Vocontian Trough (SE France), Bull. Cent. Rech. Explor. Prod. Elf Aquitaine, 17, $205-$ 221.

Emmanuel, L., M. Renard, R. Cubaynes, M. de Rafélis, M. Hermoso, L. Le Callonnec, A. le Solleuz, and J. Rey (2006), Les "schistes carton" du Quercy (Tarn-France): La signature lithologique d'un événement de dissociation d'hydrates de méthane au cours du Toarcien inférieur: Implications sur les corrélations entre les domaines boréaux et téthysiens, Bull. Soc. Geol. Fr. 177, 237-247, doi:10.2113/gssgfbull. 177.5.237.

Farrimond, P., G. Englinton, S. C. Brassell, and H. C. Jenkyns (1989), Toarcian anoxic event in Europe: An organic geochemical study, Mar. Pet. Geol., 6, 136-147, doi:10.1016/0264 8172(89)90017-2.

Gibbs, S. J., T. J. Bralower, P. R. Bown, J. Zachos, and L. M. Bybell (2006), Decoupled shelf ocean phytoplankton productivity responses across the Paleocene-Eocene thermal maximum, Geology, 34, 233-236, doi:10.1130 G22381.1. 
Hallam, A. (1983), Early and Mid-Jurassic molluscan biogeography and the establishment of the central Atlantic seaway, Palaeogeogr. Palaeoclimatol. Palaeoecol., 43, 181-193, doi:10.1016/0031-0182(83)90010-X.

Hallam, A. (1996), Recovery of the marine fauna in Europe after the end-Triassic and Early Toarcian mass extinctions, Geol. Soc. Spec. Publ., 102, 231-236, doi:10.1144/GSL.SP. 1996.001.01.16.

Hallam, A. (1997), Estimates of the amount and rate of sea-level changes across the RhaetianHettangian and Pliensbachian-Toarcian boundaries (Latest Triassic to Early Jurassic), J. Geol. Soc. London, 154, 773-779, doi:10.1144/gsjgs. 154.5.0773.

Hanzo, M., B. Lathuillière, Y. Almeras, G. Dagallier, S. Guérin-Franiatte, F. Guillocheau, V. Huault, L. Nori, and R. Rauscher (2000), Paléoenvironnements dans le Calcaire à gryphées du Lias de Lorraine, de la carrière de Xeuilley au Bassin parisien, Eclogae Geol. Helv., 93, 183-206.

Haq, B. U., J. Hardenbol, and P. R. Vail (1988), Mesozoic and Cenozoic chronostratigraphy and cycles of sea level changes, in Sea-Level Changes: An Integrated Approach, edited by C. K. Wilgus et al., Spec. Publ. Soc. Econ. Paleontol. Mineral., 42, 71-108.

Harries, P. J., and C. T. S. Little (1999), The Early Toarcian (Early Jurassic) and the CenomanianTuronian (Late Cretaceous) mass extinctions: Similarities and contrasts, Palaeogeogr. Palaeoclimatol. Palaeoecol., 154, 39-66, doi:10.1016/S0031-0182(99)00086-3.

Hermoso, M., and F. Minoletti (2008), Nannofloral assemblage change during the Early Toarcian anoxic event in the Paris Basin and biogeochemical insights, paper presented at Foraminifera and Nannofossil Groups Joint Spring Meeting, Micropalaeontol. Soc., Tübingen, Germany, 15-17 May.

Hermoso, M., F. Minoletti, M. de Rafélis, R. E. M. Rickaby, and S. Hesselbo (2007), Uncovering high strontium content in biogenic calcite: New data from a murolith-producing coccolithophore, Eos Trans. AGU, 88(52), Fall Meet. Suppl., Abstract B44C-05.

Hermoso, M., L. Le Callonnec, F. Minoletti, M. Renard, and S. P. Hesselbo (2009), Expression of the Early Toarcian carbon-isotope negative excursion in separated microfractions (Jurassic, Paris Basin), Earth Planet. Sci. Lett., 277, 194-203, doi:10.1016/j.epsl.2008. 10.013

Hesselbo, S. P., D. R. Gröcke, H. C. Jenkyns, C. J. Bjerrum, P. Farrimond, H. S. Morgans Bell, and O. R. Green (2000), Massive dissociation of gas hydrate during a Jurassic oceanic event, Nature, 406, 392-395, doi:10.1038/ 35019044

Hesselbo, S. P., H. C. Jenkyns, L. V. Duarte, and L. C. V. Oliveira (2007), Carbon-isotope record of the Early Jurassic (Toarcian) oceanic anoxic event from fossil wood and marine carbonate (Lusitanian Basin, Portugal), Earth Planet. Sci. Lett., 253, 455-470, doi:10.1016/ j.epsl.2006.11.009.

Hollander, D. J., G. Bessereau, S. Belin, and A. Y. Huc (1991), Organic matter in the Early Toarcian shales, Paris Basin, France: A response to environmental changes, Rev. Inst. Fr. Pet., 46, 543-562.

Huckriede, H., and D. Meischner (1996), Origin and environment of manganese-rich sediments within black-shale basins, Geochim. Cosmochim. Acta, 60, 1399-1413, doi:10. 1016/0016-7037(96)00008-7.
Irwin, H., C. Curtis, and M. Coleman (1977), Isotopic evidence for source of diagenetic carbonates formed during burial of organic-rich sediments, Nature, 269, 209-213, doi:10.1038/ $269209 \mathrm{a} 0$

Jacobson, R. L., and H. E. Usdowski (1976), Partitioning of strontium between calcite, dolomite and liquids: An experimental study under higher temperature diagenetic conditions, and a model for the prediction of mineral pairs for geothermometry, Contrib. Mineral. Petrol., 59, 171-185, doi:10.1007/BF00371306.

Jarvis, I., A. M. Murphy, and A. S. Gale (2001), Geochemistry of pelagic and hemipelagic carbonates: Criteria for identifying systems tracts and sea-level change, J. Geol. Soc. London, 158, 685-696.

Jenkyns, H. C. (1985), The Early Toarcian and Cenomanian-Turonian anoxic events in Europe: Comparisons and contrasts, Int. J. Earth Sci., 74, 505-518.

Jenkyns, H. C. (1988), The Early Toarcian (Jurassic) event: Stratigraphy, sedimentary and geochemical evidence, Am. J. Sci., 288, 101-151.

Jenkyns, H. C. (2003), Evidence for rapid climate change in the Mesozoic-Paleogene greenhouse, Proc. R. Soc. London, Ser. A, $361,1885-1916$.

Jenkyns, H. C., B. Géczy, and J. D. Marshall (1991), Jurassic manganese carbonates of central Europe and the Early Toarcian anoxic event, J. Geol., 99, 137-149, doi:10.1086/ 629481.

Jenkyns, H. C., D. R. Gröcke, and S. P. Hesselbo (2001), Nitrogen isotope evidence for water mass denitrification during the Early Toarcian (Jurassic) oceanic anoxic event, Paleoceanography, 16, 593-603, doi:10.1029/2000PA000558.

Jenkyns, H. C., C. E. Jones, D. R. Gröcke, S. P. Hesselbo, and D. N. Parkinson (2002), Chemostratigraphy of the Jurassic system: Applications, limitations and implications for paleoceanography, J. Geol. Soc. London, 159 , 351-378, doi:10.1144/0016-764901-130.

Jourdan, F., G. Féraud, H. Bertrand, M. K Watkeys, and P. R. Renne (2008), The ${ }^{40} \mathrm{Ar} /{ }^{39} \mathrm{Ar}$ ages of the sill complex of the Karoo large igneous province: Implications for the Pliensbachian-Toarcian climate change, Geochem Geophys. Geosyst., 9, Q06009, doi:10.1029/ 2008GC001994.

Karlin, R., and S. Levi (1983), Diagenesis of magnetic minerals in recent haemipelagic sediments, Nature, 303, 327-330, doi:10.1038/ $303327 \mathrm{a} 0$.

Kemp, D. B., A. L. Coe, A. S. Cohen, and L. Schwark (2005), Astronomical pacing of methane release in the Early Jurassic period, Nature, 437, 396-399, doi:10.1038/nature04037.

Kinsman, D. J. (1969), Interpretation of $\mathrm{Sr}^{2+}$ concentrations in carbonate minerals and rocks, J. Sediment. Petrol., 39, 486-508.

Küspert, W. (1982), Environmental changes during oil shale deposition as deduced from stable isotope ratios, in Cyclic and Event Stratification, edited by G. Einsele and A. Seilacher, pp. 482-501, Springer, Berlin.

Langer, G., N. Gussone, G. Nehrke, U. Riebesell, A. Eisenhauer, H. Kuhnert, B. Rost, S. Trimborn, and S. Thomas (2006), Coccolith strontium to calcium ratio in Emiliania huxleyi: The dependence on seawater strontium and calcium concentrations, Limnol. Oceanogr., 51, 310-320.

Little, C. T. S., and M. J. Benton (1995), Early Jurassic mass extinction-A global long term event, Geology, 23, 495-498, doi:10.1130/
0091-7613(1995)023<0495:EJMEAG>2.3. $\mathrm{CO} ; 2$

Mattioli, E., B. Pittet, R. Bucefalo-Palliani, H. J. Röhl, and E. Morettini (2004), Phytoplankton evidence for the timing and correlation of palaeoceanographical changes during the Early Toarcian oceanic anoxic event (Early Jurassic) J. Geol. Soc. London, 161, 685-693, doi:10.1144/0016-764903-074.

Mattioli, E., B. Pittet, G. Suan, and S. Mailliot (2008), Calcareous nannoplankton changes across the Early Toarcian oceanic anoxic event in the western Tethys, Paleoceanography, 23, PA3208, doi:10.1029/2007PA001435.

Mattioli, E., B. Pittet, L. Petitpierre, and S. Mailliot (2009), Dramatic decrease of pelagic carbonate production by nannoplankton across the Early Toarcian anoxic event (T-OAE), Global Planet. Change, 65, 134-145, doi:10.1016/j.gloplacha. 2008.10.018.

McArthur, J. M. (2007), Comment on "Carbonisotope record of the Early Jurassic (Toarcian) oceanic anoxic event from fossil wood and marine carbonate (Lusitanian Basin, Portugal)" by Hesselbo S., Jenkyns H. C., Duarte L. V. and Oliveira L. C. V., Earth Planet. Sci. Lett., 259, 634-639, doi:10.1016/j.eps1.2007. 04.055 .

McArthur, J. M., D. T. Donovan, M. F. Thirlwall, B. W. Fouke, and D. Mattey (2000), Strontium isotope profile of the Early Toarcian (Jurassic) oceanic anoxic event, the duration of ammonite biozones, and belemnite paleotemperatures, Earth Planet. Sci. Lett., 179, 269-285, doi:10.1016/S0012-821X(00)00111-4.

McArthur, J. M., T. J. Algeo, B. van de Schootbrugge, Q. Li, and R. J. Howarth (2008a), Basinal restriction, black shales, Re-Os dating, and the Early Toarcian (Jurassic) oceanic anoxic event, Paleoceanography, 23, PA4217, doi:10.1029/2008PA001607.

McArthur, J. M., A. S. Cohen, A. L. Coe, D. B. Kemp, R. J. Bailey, and D. G. Smith (2008b), Discussion on the Late Paleocene-Early Eocene and Toarcian (Early Jurassic) carbon isotope excursions: A comparison of their time scales, associated environmental change, causes and consequences, J. Geol. Soc., 164 , $1093-1108$.

McElwain, J. C., J. Wade-Murphy, and S. P. Hesselbo (2005), Changes in carbon dioxide during an oceanic anoxic event linked to intrusion into Gondwana coals, Nature, 435, 479482, doi: $10.1038 /$ nature 03618 .

Meister, P., J. A. McKenzie, C. Vasconcelos, S. Bernasconi, M. Franck, M. Gutjahr, and D. P. Schrag (2007), Dolomite formation in the dynamic deep biosphere: Results from the Peru Margin, Sedimentology, 54, 1007-1032, doi:10.1111/j.1365-3091.2007.00870.x.

Mélières, F. (1991), Nature et origine des alternances métriques marnes-calcaires d'âge bajocien du forage de Sancerre-Couy (Cher, France), Bull. Soc. Geol. Fr., 162, 953-970.

Michard, A. (1960), Sur la variété des processus de genèse dolomitique, C. R. Hebd. Seances Acad. Sci., 251, 3025-3027.

Minoletti, F., M. Hermoso, and V. Gressier (2009), Separation of sedimentary micronsized particles for palaeoceanography and calcareous nannoplankton biogeochemistry, Nat. Protoc., 4, 14-24, doi:10.1038/nprot. 2008.200.

Morard, A., J. Guex, A. Bartolini, E. Morettini, and P. de Wever (2003), A new scenario for the Domerian-Toarcian transition, Bull. Soc. Geol. Fr. 174, 351-356, doi:10.2113/174.4.351. 
Moulin, M., A. E. Jay, F. Fluteau, J. S. Marsh, M. Gerard, and X. Quidelleur (2008), Magnetostratigraphy of the Naude's Nek Section (Karoo traps): News constraints on the eruptive sequence, Eos Trans. $A G U, 89(53)$, Fall Meet. Suppl., Abstract V53A-2137.

Pálfy, J., and P. L. Smith (2000), Synchrony between Early Jurassic extinction, oceanic anoxic event, and the Karoo-Ferrar flood basalt volcanism, Geology, 28, 747-750, doi:10.1130/0091-7613(2000)28<747: SBEJEO $>2.0 . \mathrm{CO} ; 2$.

Pálfy, J., R. R. Parrish, and P. L. Smith (1997), A $\mathrm{U}-\mathrm{Pb}$ age from the Toarcian (Lower Jurassic) and its use for time scale calibration through error analysis of biochronologic dating, Earth Planet. Sci. Lett., 146, 659-675, doi:10.1016/ S0012-821X(96)00241-5.

Pancost, R. D., N. Crawford, S. Magness, A. Turner, H. C. Jenkyns, and J. R. Maxwell (2004), Further evidence for the development of photic-zone euxinic conditions during Mesozoic oceanic anoxic events, J. Geol. Soc. London, 161, 353-364.

Pearce, C. R., A. S. Cohen, A. L. Coe, and K. W. Burton (2008), Molybdenum isotope evidence for global ocean anoxia coupled with perturbations to the carbon cycle during the Early Jurassic, Geology, 36, 231-234, doi:10.1130/ G24446A.1.

Raiswell, R., and R. A. Berner (1985), Pyrite formation in euxinic and semi-euxinic sediments, Am. J. Sci., 285, 710-724.

Renard, M. (1986), Pelagic carbonate chemostratigraphy $\left(\mathrm{Sr}, \mathrm{Mg},{ }^{18} \mathrm{O},{ }^{13} \mathrm{C}\right), \mathrm{Mar}$. Micropaleontol., 10, 117-164, doi:10.1016/ 0377-8398(86)90027-7.

Renard, M., and P. Blanc (1972), Influence des conditions de mise en solution (choix de l'acide, température, durée de l'attaque) dans le dosage des éléments en traces des carbonates, C. R. Seances Acad. Sci., Ser. D, 274, 632-635.

Richter, F. M., and Y. Liang (1993), The rate and consequences of $\mathrm{Sr}$ diagenesis in deep-sea carbonates, Earth Planet. Sci. Lett., 117, 553565, doi:10.1016/0012-821X(93)90102-F.

Rickaby, R. E. M., D. P. Schrag, I. Zondervan, and U. Riebesell (2002), Growth rate dependence of $\mathrm{Sr}$ incorporation during calcification of Emiliania huxleyi, Global Biogeochem. Cycles, 16(1), 1006, doi:10.1029/2001GB001408.

Riebesell, U., I. Zondervan, B. Rost, P. D. Tortell, R. E. Zeebe, and F. M. M. Morel (2000), Reduced calcification of marine plank- ton in response to increased atmospheric $\mathrm{CO}_{2}$, Nature, 407, 364-367, doi:10.1038/35030078. Röhl, H.-J., A. Schmid-Röhl, W. Oschmann, A. Frimmel, and L. Schwark (2001), The Posidonia Shale (Lower Toarcian) of SW-Germany: An oxygen-depleted ecosystem controlled by sea level and palaeoclimate, Palaeogeogr. Palaeoclimatol. Palaeoecol., 165, 27-52, doi:10.1016/S0031-0182(00)00152-8.

Rost, B., and U. Riebesell (2004), Coccolithophores and the biological pump: Responses to environmental changes, in Coccolithophores: From Molecular Processes to Global Impact, edited by H. R. Thierstein and J. R. Young, pp. 76-99, Springer, Berlin.

Schwark, L., and A. Frimmel (2004), Chemostratigraphy of the Posidonia black shale, SW Germany: II. Assessment of extent and persistence of photic-zone anoxia using aryl isoprenoid distributions, Chem. Geol., 206, $231-$ 248, doi:10.1016/j.chemgeo.2003.12.008.

Stoll, H. M., and D. P. Schrag (2000), Coccolith $\mathrm{Sr} / \mathrm{Ca}$ as a new indicator of coccolithophorid calcification and growth rate, Geochem. Geophys. Geosyst., 1(5), 1006, doi:10.1029/ 1999GC000015.

Suan, G., B. Pittet, I. Bour, E. Mattioli, L. V. Duarte, and S. Mailliot (2008a), Duration of the Early Toarcian carbon isotope excursion deduced from spectral analysis: Consequence for its possible causes, Earth Planet. Sci. Lett., 267, 666-679, doi:10.1016/j.eps1.2007. 12.017

Suan, G., E. Mattioli, B. Pittet, S. Mailliot, and C. Lécuyer (2008b), Evidence for major environmental perturbation prior to and during the Toarcian (Early Jurassic) oceanic anoxic event from the Lusitanian Basin, Portugal, Paleoceanography, 23, PA1202, doi:10.1029/ 2007 PA001459.

Svensen, H., S. Planke, L. Chevallier, A. MaltheSørenssen, F. Corfu, and B. Jamtveit (2007), Hydrothermal venting of greenhouse gases triggering Early Jurassic global warming, Earth Planet. Sci. Lett., 256, 554-566, doi:10.1016/j.eps1.2007.02.013.

Tremolada, F., B. van de Schootbrugge, and E. Erba (2005), Early Jurassic schizosphaerellid crisis in Cantabria, Spain: Implications for calcification rates and phytoplankton evolution across the Toarcian oceanic anoxic event, Paleoceanography, 20, PA2011, doi:10.1029/ 2004PA001120.

van Breugel, Y., M. Baas, S. Schouten, E. Mattioli, and J. S. Sinninghe Damsté (2006), Isorenieratane record in black shales from the Paris Basin,
France: Constraints on recycling of respired $\mathrm{CO}_{2}$ as a mechanism for negative carbon isotope shifts during the Toarcian oceanic anoxic event, Paleoceanography, 21, PA4220, doi:10.1029/2006PA001305.

van de Schootbrugge, B., J. M. McArthur, T. R. Bailey, Y. Rosenthal, J. D. Wright, and K. G. Miller (2005), Toarcian oceanic anoxic event: An assessment of global causes using belemnite $\mathrm{C}$ isotope records, Paleoceanography, 20 , PA3008, doi:10.1029/2004PA001102.

Vetö, I., A. Demény, E. Hertelendi, and M. Hetényi (1997), Estimation of primary productivity in the Toarcian Tethys - A novel approach based on TOC, reduced sulfur and manganese contents, Palaeogeogr. Palaeoclimatol. Palaeoecol., 132, 355-371, doi:10.1016/S0031-0182 (97)00053-9.

Wignall, P. B. (2001), Large igneous provinces and mass extinctions, Earth Sci. Rev., 53, $1-$ 33, doi:10.1016/S0012-8252(00)00037-4.

Wignall, P. B., R. J. Newton, and C. T. S. Little (2005), The timing of palaeoenvironmental change and cause-and-effect relationships during the Early Jurassic mass extinction in Europe, Am. J. Sci., 305, 1014-1032, doi:10.2475/ajs.305.10.1014

Wignall, P. B., J. M. McArthur, C. T. S. Little, and A. Hallam (2006), Palaeoceanography: Methane release in the Early Jurassic period Nature, 441, E5, doi:10.1038/nature04905.

Wilkin, R. T., and H. L. Barnes (1997), Formation processes of framboidal pyrite, Geochim. Cosmochim. Acta, 61, 323-339, doi:10.1016/ S0016-7037(96)00320-1.

Wilkin, R. T., H. L. Barnes, and S. L. Brantley (1996), The size distribution of framboidal pyrite in modern sediments: An indicator of redox conditions, Geochim. Cosmochim. Acta, 60, 3897-3912, doi:10.1016/0016-7037(96) 00209-8.

M. de Rafélis, L. Emmanuel, L. Le Callonnec, F. Minoletti, and M. Renard, Laboratoire Biominéralisations et Environnements Sédimentaires, ISTeP, UMR 7193, UPMC Université Paris 6 , Case Postale 116, 4 Place Jussieu, F-75005 Paris, France.

M. Hermoso, S. P. Hesselbo, H. C. Jenkyns, and R. E. M. Rickaby, Department of Earth Sciences, University of Oxford, Parks Road Oxford OX1 3PR, UK. (michael.hermoso@) earth.ox.ac.uk) 